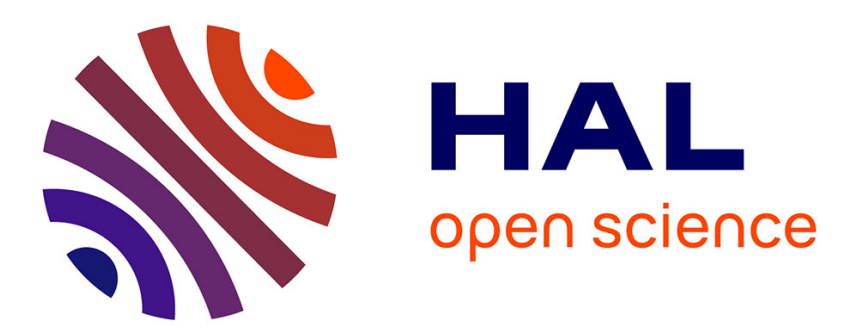

\title{
Fluorescence enlightens RND pump activity and the intrabacterial concentration of antibiotics
}

\author{
Muriel Masi, Estelle Dumont, Julia Vergalli, Jelena Pajovic, Matthieu \\ Réfrégiers, Jean-Marie Pages
}

\section{- To cite this version:}

Muriel Masi, Estelle Dumont, Julia Vergalli, Jelena Pajovic, Matthieu Réfrégiers, et al.. Fluorescence enlightens RND pump activity and the intrabacterial concentration of antibiotics. Research in Microbiology, 2018, 169 (7-8), pp.432-441. 10.1016/j.resmic.2017.11.005 . hal-02110917

\section{HAL Id: hal-02110917 \\ https://hal-amu.archives-ouvertes.fr/hal-02110917}

Submitted on 25 Apr 2019

HAL is a multi-disciplinary open access archive for the deposit and dissemination of scientific research documents, whether they are published or not. The documents may come from teaching and research institutions in France or abroad, or from public or private research centers.
L'archive ouverte pluridisciplinaire HAL, est destinée au dépôt et à la diffusion de documents scientifiques de niveau recherche, publiés ou non, émanant des établissements d'enseignement et de recherche français ou étrangers, des laboratoires publics ou privés. 


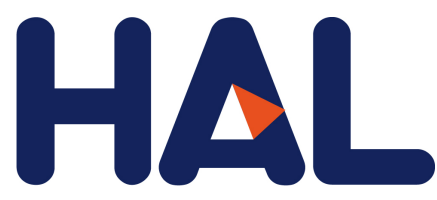

archives-ouvertes

\title{
Fluorescence enlightens RND pump activity and the intrabacterial concentration of antibiotics
}

\author{
Muriel Masi, Estelle Dumont, Julia Vergalli, Jelena Pajovic, Matthieu \\ Réfrégiers, Jean-Marie Pages
}

\section{To cite this version:}

Muriel Masi, Estelle Dumont, Julia Vergalli, Jelena Pajovic, Matthieu Réfrégiers, et al.. Fluorescence enlightens RND pump activity and the intrabacterial concentration of antibiotics. Research in Microbiology, Elsevier, 2018, 169 (7-8), pp.432-441. 10.1016/j.resmic.2017.11.005 hal-02110917

\section{HAL Id: hal-02110917 \\ https://hal-amu.archives-ouvertes.fr/hal-02110917}

Submitted on 25 Apr 2019

HAL is a multi-disciplinary open access archive for the deposit and dissemination of scientific research documents, whether they are published or not. The documents may come from teaching and research institutions in France or abroad, or from public or private research centers.
L'archive ouverte pluridisciplinaire HAL, est destinée au dépôt et à la diffusion de documents scientifiques de niveau recherche, publiés ou non, émanant des établissements d'enseignement et de recherche français ou étrangers, des laboratoires publics ou privés. 
in Microbiology

Elsevier Editorial System(tm) for Research

Manuscript Draft

Manuscript Number: RESMIC-D-17-00237R2

Title: Fluorescence enlightens the RND pump activity and the intrabacterial concentration of antibiotics

Article Type: Special Issue Paper

Keywords: Antibiotic; bacterial imaging; drug efflux pumps; Gram-negative bacteria; multidrug resistance; transporters

Corresponding Author: Dr. Jean-Marie PAGES, Ph.D, M.D.,

Corresponding Author's Institution: Faculté de Médecine

First Author: Muriel MASI, MD, PhD,

Order of Authors: Muriel MASI, MD,PhD, ; Estelle DUMONT, MD, PhD, ; Julia VERGALLI, MD, PhD, ; Jelena PAJOVIC, MD; Matthieu REEREGIERS, MD, PhD, ; Jean-Marie PAGES, Ph.D, M.D.,

Abstract: To understand the antibiotic resistance in Gram-negative bacteria, a key point is to investigate antibiotic accumulation which is defined by influx and efflux. Several methods exist to evaluate the membrane permeability and efflux pump activity but they present some disadvantages and limitations. An optimized spectrofluorimetric method using the intrinsic tryptophan fluorescence as internal standard as well as a complementary microfluorimetric assay following the time-course accumulation in intact individual cells have been developed. Comparing the latter population and single cell approaches can lead to the understanding of the phenotypic heterogeneity within a population. The two methodologies lead to the determination of parameters, concentration, accumulation rates, localization that contribute to emerging concepts (RTC2T, SICAR) with the aim to identify and detail the antibiotic chemotypes that are involved in influx/efflux. 
Fluorescence enlightens the RND pump activity and the intra-bacterial concentration of antibiotics

Muriel Masi ${ }^{\mathrm{a}}$, Estelle Dumont ${ }^{\mathrm{a}}$, Julia Vergalli ${ }^{\mathrm{a}}$, Jelena Pajovic ${ }^{\mathrm{b}, \mathrm{c}}$, Matthieu Réfrégiers ${ }^{\mathrm{b}}$, Jean-Marie Pagès ${ }^{\mathrm{a},{ }^{*}}$

a UMR_MD1, Aix-Marseille Univ, IRBA, TMCD2, Facultés de Médecine et de Pharmacie, 27 bd Jean Moulin, 13385 Marseille cedex 05, France

b DISCO beamline, Synchrotron Soleil, L'Orme des Merisiers, Saint-Aubin BP 48, 91192 Gif-sur-Yvette cedex, France

c University of Belgrade, Faculty of Physics, Studentski trg 12, 11001 Belgrade, Serbia

muriel.masi@univ-amu.fr (M. Masi)

estelle.dumont@univ-amu.fr (E. Dumont)

julia.vergalli@univ-amu.fr (J. Vergalli)

unedogled@gmail.com (J. Pajovic)

matthieu.refregiers@synchrotron-soleil.fr (M. Réfrégiers)

jean-marie.pages@univ-amu.fr (J.M. Pagès) *Correspondence and reprints 


\section{Abstract}

To understand the antibiotic resistance in Gram-negative bacteria, a key point is to investigate antibiotic accumulation which is defined by influx and efflux. Several methods exist to evaluate the membrane permeability and efflux pump activity but they present some disadvantages and limitations. An optimized spectrofluorimetric method using the intrinsic tryptophan fluorescence as internal standard as well as a complementary microfluorimetric assay following the time-course accumulation in intact individual cells have been developed. Comparing the latter population and single cell approaches can lead to the understanding of the phenotypic heterogeneity within a population. The two methodologies lead to the determination of parameters, concentration, accumulation rates, localization that contribute to emerging concepts (RTC2T, SICAR) with the aim to identify and detail the antibiotic chemotypes that are involved in influx/efflux.

\section{Keywords}

Antibiotic; bacterial imaging; drug efflux pumps; Gram-negative bacteria; multidrug resistance; transporters 


\section{Introduction}

For several years antibiotic resistance has been an increasing threat to public health, it now concerns all major bacterial pathogens and antibiotic classes. A key challenge in antibiotic therapy is to determine the parameters modulating the in cellulo drug concentration required for a therapeutic action [1-3]. In Gram-negative antibacterial research, the concern is to evaluate the antibiotic permeation across the outer and inner membranes that constitute the bacterial envelope [4-6]. Translocation through the membrane barriers to reach the inhibitory concentration inside the bacterium is a pivotal step for antibacterial molecules [7-12].

The discovery and the development of new antimicrobials mostly rely on their capacity to reach critical concentrations $\left(\mathrm{C}_{\text {inh }}\right)$ at the vicinity of their intracellular target $[13,14]$. Despite several decades of studies focused on antibiotic activity against bacterial cells using different approaches, no consensus for the analysis of the kinetics and accumulation of antibacterial agents in individual bacterium and in bacterial populations exists to understand the drug translocation into living bacteria as a first step of drug action [15]. Currently the lack of appropriate assays is a substantial bottleneck for the optimization of new molecules regarding permeability and to increase antimicrobial activity in intact bacterial cells. TRANSLOCATION consortium supports the development of reliable and robust methods to quantify penetration and efflux processes in Gram-negative bacteria (see "TRANSLOCATION Project: www.imi.europa.eu/content/translocation; [13]).

Several methods and protocols have been developed in order to quantify and visualize the intra-bacterial concentrations of antibiotics and the role of membrane- 
associated mechanisms of resistance in the accumulation of antibacterial drugs (Influx, Efflux). Studies performed during this last decade have increased our understanding of how individual bacterial cells and bacterial populations control the internal concentration of antibiotics by using appropriate transport systems. In addition, original ways are now available to investigate in depth the drug translocation across bacterial membranes. Mass spectrometry appears as a promising method to determine the intracellular accumulation of label-free compounds $[14,16]$. Ultimately, this approach might help to characterize the permeability of various potential drugs, quantify antibiotic accumulation and meet the requirements of high throughput structure-activity relationship programs. In the case of naturally fluorescent drugs, intracellular accumulation can be monitored using a deep ultraviolet (DUV) light source that allows the detection by microspectrofluorimetry $[17,18]$. For example, fluoroquinolone antibiotics contain a quantum-yield of fluorescence sufficient to monitor their accumulation and localization in bacterial cells without requiring any addition of external probe.

The information obtained by using these new approaches, combined with the knowledge inherited from more traditional approaches, are critical for our understanding of drug transport and have implications for future strategies and for designing new drugs to combat antibiotic resistance.

Therefore, it is important to provide a recent and thoughtful perspective to the community that discusses the recent methods available for studying antibiotic penetration and correlation to antibacterial activities. From these studies and others, a new perspective emerges on how to capture and correlate the modes of action and kinetics of antibiotic uptake inside bacterial cells. 


\section{Detection of efflux activity}

The tripartite RND efflux pump family is well conserved in clinically relevant Enterobacteriaceae such as Escherichia coli, Enterobacter and Klebsiella spp, Salmonella enterica, as well as in other Gram-negative pathogens like Acinetobacter baumannii, Neisseria gonorrhoeae, and Pseudomonas aeruginosa [8,12].

Based on its broad range substrate selectivity and its high expression level in clinical resistant isolates, it is a major contributor to the MDR resistance in these species. The archetypal E. coli AcrAB-TolC (or MexAB-OprM in P. aeruginosa) is the best structurally characterized RND efflux complex, since the crystal structures of the individual AcrA, AcrB and TolC have been solved and assembled complexes have been proposed [19-27]. While structural models and dynamic simulations are relatively well advanced (see accompanying reviews in this special issue), the characterization of AcrAB-TolC (as well as other efflux pumps) from mechanistic and kinetic point of view remains mainly partial as it relies on the comparison of minimal inhibitory concentration (MIC) values between of wild-type and acrAB-tolC deleted strains.

\section{The radiolabeled assay}

The first assay developed to evaluate the efflux activity in bacterial cells was the measurement of radiolabeled drug accumulation in resistant strains [28-30]. The efflux activity was demonstrated in several MDR isolates by using CCCP or other poisons that collapse the energy component of the efflux, and consequently block the pump and restored the intracellular antibiotic concentration at a level similar to the normal susceptible reference strains. The radiolabeled assay presents some advantages about precision, sharpness of quantification but also large disadvantages 
regarding the availability/production of marked molecules, safety protocols, internal controls, low spatial resolution and waste treatments.

\section{The ethidium bromide-agar based method}

The accumulation of ethidium bromide ( $\mathrm{EtBr}$ ) was used to follow the activity of efflux pump in various bacterial species [31,32]. Later, a simple and instrument-free method that uses agar plates containing increasing concentrations of EtBr, as a fluorescent efflux pump substrate, has been developed to detect the presence of active efflux in swabbed strains [33]. This method, called the EtBr-agar cartwheel method, has been validated to identify overexpression of efflux pumps that contribute to MDR phenotypes in collections of clinical strains [34-37]. Briefly, it is based on that the minimal concentration of $\mathrm{EtBr}(\mathrm{MEB})$ in agar that produces fluorescence associated to bacteria growing at the surface of the agar defines the maximum extrusion rate of this substrate. Data showed that the MEB of strains that overexpress efflux pumps is considerably higher than that of reference strains. An example of results applied to one reference (ATCC15038) and eight MDR strains of E. aerogenes is shown: $E$. aerogenes HMEA11 showed no fluorescence at $1.5 \mu \mathrm{g} / \mathrm{ml}$ EtBr whereas the others including ATCC15038 fluoresced at $0.05 \mu \mathrm{g} / \mathrm{ml} \mathrm{EtBr}$ (Figure 1).

The main disadvantage of this method is the toxicity of the used dye, EtBr, the corresponding safety protocols require during the assays and the waste treatments of plates, effluents, etc. Moreover, like other dyes, EtBr is not per se an antibiotic and it is difficult to correlate an internal concentration, to an antibiotic activity and a clinical relevance. 


\section{The semi-automated "real-time" method using fluorescent probes}

It was necessary to develop fast, easy-to-perform and reliable methods in order to study the real-time efflux of a pre-accumulated compound in bacteria expressing various efflux pumps.

Automated methods are advantageous in that they allow quantification of influx and efflux levels on a real-time basis and can be set up for medium throughput analysis of bacterial strains. The readability and reliability of this approach requires (i) that the chosen molecule does not alter bacterial metabolic functions at the working ranges, exhibits a good penetration through the outer membrane (and inner membrane), is a substrate of efflux pumps and yields high signal only when inside the cells and (ii) a protocol that detects the variation of this signal when molecules are expelled by the efflux activity.

Several fluorescent probes for which the spectroscopic properties change upon entering the cells are particularly appropriate for these assays: the bacterial cells can be preloaded with these dyes before triggering the efflux by adding an energy source. Two lipophilic compounds, Nile Red and 1,2'-dinaphthylamine(1,2'-DNA) that give negligible fluorescence in aqueous solutions but become strongly fluorescent in nonpolar environments such as bacterial membranes, have been described for measuring the efflux activity and the effect of putative efflux pump inhibitors [38-41]. After loading, cells are then energized by the addition of glucose, which produces the proton motive force in the inner membrane, energizes the RND pump and triggers the dye efflux across the envelope (Fig. 2). However, special attention should also be given to the self-quenching of the dye fluorescence in case of high concentration close to the bacterial membranes or to the quenching induced by other chemicals (e.g. efflux pump blockers/inhibitors) used in combination. In addition, similarly to 
$\mathrm{EtBr}$, these molecules are not antibiotics and the correlation between internal concentrations and antibacterial activities are not possible. Moreover, an internal standard is required to efficiently compare the data obtained in various bacterial series. The efflux activity was demonstrated in several MDR isolates by using CCCP or other poisons that collapse the energy component of the efflux, and consequently block the pump and restore the intracellular antibiotic concentration at a level similar to the normal susceptible reference strains. Interestingly, this approach can also be used to screen for molecules that inhibit efflux $[40,42]$.

\section{Monitoring $\beta$-lactam efflux using rates of $\beta$-lactamase-mediated hydrolysis}

The knowledge of the kinetic behavior of efflux pumps is essential in our attempts to understand and quantify their contribution to antibiotic resistance. No success was achieved until the Nikaido laboratory determined the kinetic constants for several $\beta$ lactams, including penicillins and cephalosporins, in intact cells of E. coli [43-45]. First, the intracellular concentration of $\beta$-lactams, which accumulate in the periplasm, was calculated by from their hydrolysis rate by periplasmic $\beta$-lactamases. Then, the rate of efflux was calculated as the difference between the calculated rate of influx and the measured rate of hydrolysis. Results obtained with nitrocefin - a chromogenic cephalosporin - showed a $K_{\mathrm{m}}$ of about $5 \mu \mathrm{M}$ and a $V_{\max }$ around 0.025 $\mathrm{nmol} / \mathrm{mg} / \mathrm{s}$, which correspond to a $k_{\mathrm{cat}} \approx 10 / \mathrm{s}$ based on the cellular content of AcrB. Overall, penicillins present a stronger apparent affinity $(\approx 1 \mu \mathrm{M})$ for $A c r B$ than cephalosporins (ranging from 5 to $300 \mu \mathrm{M}$ ). In contrast to nitrocefin, the other cephalosporins had higher values of $K_{\mathrm{m}}(\approx 20 \mu \mathrm{M}$ for cefamandole, $\approx 90 \mu \mathrm{M}$ for cephalotin, $\approx 300 \mu \mathrm{M}$ for cephaloridine). Interestingly, this study showed that low affinity substrates such as cephaloridine are pumped out very efficiently $\left(k_{\text {cat }} \approx 290 /\right.$ s) 
when the periplasmic concentration exceeds $100 \mu \mathrm{M}$, which is far superior to the MIC for this antibiotic $(\approx 0.5 \mu \mathrm{M})$. This finding pointed that efflux is not that important as long as it occurs in the range of intracellular concentration superior to the MIC.

\section{Determination of antibiotic accumulation in bacteria using UV fluorescence microscopy/spectroscopy methods}

Membrane-associated mechanisms of bacterial MDR (i.e. membrane impermeability and drug efflux) act to efficiently limit the concentration of antibiotics at the vicinity of their targets. Therefore, a key point in the understanding of these mechanisms is to determine and compare the intracellular concentration of antibiotics in bacterial cells accordingly to their phenotypic and genotypic status. Several approaches have been developed in the past by using plate assays $[46,47]$ and fluorimetry [48], mainly for measuring the accumulation of tetracyclines and fluoroquinolones by Enterobacteriaceae as reported previously [49,50].

Quinolones are powerful antibiotics that inhibit the activity of DNA gyrase and topoisomerase IV enzymes located in the cytoplasm. The ability of quinolones to pass the bacterial membranes to reach their intracellular targets is a key factor for their activity. In Gram-negative bacteria, fluoroquinolones have been shown to use the outer membrane porins [51] to efficiently accumulate inside the cell. The mechanism of permeation across the inner membrane is less clear, but most likely involves an energy-independent passive diffusion mechanism. Moreover, quinolones are also excellent substrates of efflux pumps [52,53].

In 1989, Chapman \& Georgopapadakou have developed a fluorimetric method based on the natural fluorescence of the quinolone nucleus present in 
fluoroquinolones such as the clinically used ciprofloxacin and norfloxacin [48]. Several adaptations have improved the spectrofluorimetry of cell lysates and allow a precise quantification of the antibiotic content (in $\mathrm{ng} /$ bacterial cell) in a given bacterial cell using a calibration curve. Various publications report the determination of fluoroquinolone concentration in various bacterial species [14].

An optimized method to determine the fleroxacin accumulation inside Enterobacter aerogenes resistant strains that overproduced AcrAB-TolC efflux pump has been recently reported [17]. After incubation, the bacterial cells are washed onto a sucrose cushion in order to overcome problems of reproducibility mainly caused by nonspecific adsorption of antibiotic molecules at the bacterial surface [17]. Moreover, special attention has be given to the spectral properties of the fluorescent molecule (fleroxacin, ciprofloxacin) in order to monitor its fluorescence signal in bacterial lysates and to integrate an internal fluorescence standard, the intrinsic tryptophan fluorescence, in the protocol $[17,54]$. These special improvements have allowed generating comparative assays between various bacterial strains and species $[18,54,55]$. Furthermore, this internal standard that insures the quantitative valuation of various drugs/antibiotics on different bacterial strains is necessary for a comparative validation of other methods (such as mass spectrometry) for which no intrinsic standard has been selected yet.

About $E$. aerogenes and $E$. coli strains, the data indicate that the steady-state accumulation was stable after an incubation time of 10-15 minutes for the strains without AcrAB or overproducing the efflux pump. The CCCP addition during the assay with AcrAB overproducer strain restores the accumulation plateau observed in the acr $A B$ deleted strain (Fig. 3). To reach the best validation and robustness interval of this approach it is absolutely required that the used molecule (i) does not kill the 
bacteria at the used concentration during the incubation times, a parameter which can be checked by survival assays, (ii) exhibits a good penetration through the outer membrane (and inner membrane), (iii) is a substrate of efflux pumps as documented by the susceptibility determined in isogenic strains in parallel and by using effluxdeleted cells or incubation in the presence of CCCP [17], and (iv) importantly cause non-overlapping signal with the intrinsic internal standard (e.g. tryptophan signal). Moreover, the signal must be detected in intact bacterial cell (microspectrofluorimetry) and in bacterial lysates by using the same antibiotic concentration and generate significant variation when molecules are expelled by the efflux activity. Interestingly, this method has indicated some discrepancy in the fluoroquinolone accumulation in a bacteria population issued from the same resistant strain treated with the ionophore suggesting some phenotypic heterogeneity [17].

Combining population and single cell approaches guarantee that, if several subpopulations with extreme behavior were present, they would not be underestimated.

It can be noted that a fluorescent B-lactam derivative has been recently used to study the antibiotic accumulation and susceptibility in bacterial persisters, a subpopulation dormant bacteria showing high level of tolerance to antibiotics [56]. Bocillin is a penicillin $\mathrm{V}$ molecule coupled to a fluorescein core, BODIPY FL dye (which is spectrally similar to fluorescein). This compound has been assayed to measure the activity of efflux pump on its intra-bacterial accumulation [57]. Interestingly, the authors reported that the internal accumulation of bocillin was significantly reduced in persisters due to the efflux activity of AcrAB-TolC pump [57]. Bocillin was also used for evaluating the role of efflux pump in the resistance of nontypeable Haemophilus influenzae [58]. Although this fluorescent penicillin derivative 
is an interesting tool, it must be mentioned that due to the involvement of porin channel during the uptake of this antibiotic family, an alteration of porin characteristics (expression level, porin type or channel conductance) can change the accumulation rate and consequently can perturb the determination of efflux activity $[6,8]$.

Fluoroquinolone time-course accumulation in a single bacterial cell using UV fluorescence microscopy, microfluorimetric assay

Optimized spectrofluorimetric and microscopic methods using appropriate calibration curves and internal standards have been developed to monitor the accumulation of fluoroquinolones in Enterobacteriaceae. More recently, these approaches have been modified for the measurement of antibiotic accumulation in intact individual cells: briefly the bacterial cells are deposited between two quartz coverslips and analysed by DUV microspectrofluorimetry and/or by DUV fluorescence imaging (Fig. 4). The cell viability was checked during the time exposure. With this protocol, the time-course of accumulation of selected fluoroquinolones can be recorded in different individual cells [54] and with various incubation conditions (antibiotic concentration, efflux blocker, etc). The rate of accumulation and the plateau reached after long time of incubation can be extracted for a given antibiotic and for a given strain [54].

These technologies will offer the opportunity to determine influx and efflux parameters such as the intracellular concentration of antibiotics $\left(C_{i n}\right)$, the critical inhibitory intracellular concentration of antibiotics $\left(C_{i n h}\right)$, the precise contribution of limiting factors in reaching a $\mathrm{C}_{\text {inh }}$ (e.g. porins and efflux pumps) and the influence of chemical moieties (pharmacophores) within a specific class of antibiotic. The 
"Resident Time Concentration Close to Target" (RTC2T) concept includes the precise determination of both $C_{i n}$, and $C_{i n h}$ for a given antibacterial molecule for a given bacterial strain [14]. It will be useful to quantify the biological activity of different adjuvants in increasing the intracellular concentration of specific antibiotics in strains exhibiting membrane-associated mechanisms of resistance. The translocation of antibiotics belonging to different classes through bacterial membranes via outer membrane pores or transporters (porins or efflux pumps) is a relatively fast event and the steady-state concentrations are generally reached after short incubation times. Monitoring real-time accumulation of different quinolones showed different accumulation kinetics and steady-state accumulation levels depending on the properties (chemical and structural) of the compound in a selected bacterial background. From these observations a new concept, "Structure Intracellular Concentration Activity Relationship" (SICAR) can be elaborated to dissect the profile of antibacterial molecules [14]. SICAR connects the physicochemical drug properties to the efficacy of translocation through the bacterial membrane and the resulting intracellular accumulation [59].

These concepts have been recently used to dissect the role of chemical structures and the bacterial elements which are involved in influx (uptake) or in efflux, and guide rationale pharmacomodulation of side chains to fine-tune molecular interactions with membrane transporters. Two cases have been studied so far: an antibiotic having a periplasmic target and one having a cytoplasmic target, this gives the possibility to integrate the aspect about the cellular location.

Ceftazidime $(\mathrm{CAZ})$ is a potent cephalosporin to treat resistant bacteria in combination with B-lactamase inhibitors [60]. Different fluorescent derivatives have been synthesized to dissect the early step of translocation across bacterial outer 
membrane: CAZ* is labeled with a coumarin and its fluorescent signal is not affected by cleavage by periplasmic B-lactamases, and $\mathrm{CAZ}^{* *}$ is labeled with methoxyquinoline but becomes fluorescent only upon cleavage by periplasmic Blactamases [55]. The measure of internal accumulation and activities are performed on clinical resistant strains expressing various levels of porins and B-lactamases. By using microspectrofluorimetry and epifluorimetry, the translocation of CAZ to the periplasmic space was followed when the outer membrane barrier was permeabilized [55]. This study demonstrated the relationship between periplasmic accumulation and antibiotic activity by approaching B-lactam permeation relative to membrane permeability. Moreover, a correlation between internal accumulation and B-lactamase activity was provided that supports the pioneer model proposed by $\mathrm{H}$. Nikaido to explain the interplay existing between the membrane and enzymatic barrier for Blactams $[61,62]$.

Three selected fluoroquinolones have been studied for their accumulation in bacterial population and inside individual Gram-negative bacterial cells that express various levels of efflux pumps. For a given fluoroquinolone library, these assays allowed the determination of $\operatorname{SICAR}^{\mathrm{IN}}$ and $\operatorname{SICAR}^{\mathrm{EF}}$ indexes, the first one reflects "structure-to-penetration" relationships and the second one illustrates the correlation "structure-to-efflux". This original approach validates the SICAR concept $[14,59]$ and demonstrates the expected benefit by evidencing some pharmacophoric groups that can be involved in the penetration and in the efflux.

\section{Reconstitution of efflux pumps in proteoliposomes}

Active drug transport by efflux pumps has also been investigated after reconstitution of purified proteins into proteoliposomes. A major difficulty is to 
generate quantitatively measurable and reproducible proton gradient across the liposome membrane. Primary in vitro transport assay has been designed by the Nikaido laboratory, in which reconstituted E. coli AcrB were energized by a proton gradient generated by the addition of valinomycin, a potassium-ionophore [63]. Detection of proton transport was monitored using pyranine, a lipophilic and $\mathrm{pH}$ dependent fluorescent probe. However, the stability of the valinomycin-generated $\Delta \mathrm{pH}$ was strongly influenced by the batches of lipids used for reconstitution and other factors [64]. To overcome this problem, Picard and colleagues have developed an original system in which they used bacteriorhodopsin (BR) from Halobacter halobium to generate a photo-induced proton gradient to activate the MexB efflux pump from $P$. aeruginosa [65]. In this system, BR, MexA and MexB were reconstituted in liposomes containing pyranine. After illumination of the proteoliposomes, BR generates a transmembrane proton gradient, which is then used by MexB to transport a fluorescent dye (Hoechst 33342). In this assay, pyranine fluorescence is monitored while the proton gradient is generated or dissipated as a result of MexB efflux activity (Fig. 5). Curves show that MexB is active only in the presence of the periplasmic adaptor MexA. Recently, significant improvements of this method have been made by combining proteoliposomes containing the MexAB and OprM portions of the complex. This allowed monitoring of transport by the tripartite MexAB-OprM pump in a system that mimics the dual-membrane architecture of Gram-negative bacteria $[26,66]$.

\section{Conclusion}


Today with the development of DUV-fluorimetry method and apparatus, new tools have been proposed for studying the drug translocation across biological membrane and in living cells including bacterial population and individual bacterial cells.

Boosted by emerging and upgraded methodologies (detector, filters, etc), new concepts such as "Structure Intracellular Concentration Activity Relationship" (SICAR) and "Resident Time Concentration Close to Target" (RTC2T), have been proposed in order to bridge the molecular and membrane transport aspects [14]. Using RTC2T and SICAR methodologies, a new dissection of antibiotic translocationtransport can be defined to better understand and improve the antibiotic chemotypes that are related to permeation and efflux. The final objective will be to enhance the antibacterial efficacy of a rationally synthetized antibiotic against a resistant species.

A second important aspect is the complex relation integrating "kinetics/localization/concentration" inside the bacterial cell and the effect on bacterial metabolism and cell life. An important step is to correlate the intracellular concentration threshold and antibacterial activity for the antibiotic molecule and also for new "adjuvants" that can improve the antibiotic concentration inside the bacterium.

Conclusively, the use of this methodology that measures the real-time accumulation in different bacterial phenotypes and takes into account various chemical structures, allows analyzing the molecular bases of drug translocation. Consequently, the concept of "structure intracellular concentration activity relationship" previously proposed [14] can be extensively studied for fluorescent antibiotics. Regarding non-fluorescent molecules, a competitive assay can be designed to indirectly measure these parameters, or alternatively mass spectrometry quantification can be successfully applied [67-69]. About mass spectrometry, the 
precision of the method asks for a robust internal standard that could be used to standardize the assays carried out with various bacterial species and various strains including clinical isolates.

By using these methods available in microplates, the role of chemical side chains involved in the membrane permeation or in the efflux transport [59] can be dissected to better design drug side chains fitting well with the translocation constraints.

The future step will be the development of microfluidic-microfluorimetric approach that detect two events in the same bacterial cell, influx and efflux. This detection, should finally allow the discrimination inside the population of susceptible (fluorescence signal) and low-susceptible (no signal) individual bacteria present under specific conditions. This multiplexed approach paves the way for studying the diversity in the population, the presence of persisters, and the role of membraneassociated mechanisms of resistance in the bacterial response face to the antibiotic stimulus. 


\section{Conflict of interest}

No conflict

\section{Acknowledgements}

We thank Anne Davin-Regli, Robert Stavenger and Mathias Winterhalter for their fruitful discussions.

The research leading to the discussions presented here was conducted as part of the TRANSLOCATION consortium and has received support from the Innovative Medicines Initiatives Joint Undertaking under Grant Agreement $\mathrm{n}^{\circ} 115525$, resources which are composed of financial contribution from the European Union's seventh framework program (FP7/2007-2013) and EFPIA companies in kind contribution.

This work was also supported by Aix-Marseille Univ. and Service de Santé des Armées, and by Soleil program. 


\section{References}

1 Jones D. News and analysis: the antibacterial lead discovery challenge. Nat RevDrug Discov 2010;9:751-2.

2 Watkins RR, Bonomo R. A. Overview: global and local impact of antibiotic resistance. Infect Dis Clin North Am 2016;30:313-22.

3 Laxminarayan R, Matsoso P, Pant S, Brower C, Røttingen JA, Klugman K, et al. Access to effective antimicrobials: a worldwide challenge. Lancet 2016;387:168-75.

4 Nikaido $\mathrm{H}$. Molecular basis of bacterial outer membrane permeability revisited. Microbiol Mol Biol Rev 2003;67:593-656.

5 Zgurskaya HI, López CA, Gnanakaran S. Permeability barrier of Gramnegative cell envelopes and approaches to bypass it. ACS Infect Dis $2015 ; 1: 512-522$.

6 Pagès JM, James $C E$, Winterhalter $M$. The porin and the permeating antibiotic: a selective diffusion barrier in Gram-negative bacteria. Nat Rev Microbiol 2008;6:893-903.

7 Nikaido $\mathrm{H}$. Prevention of drug access to bacterial targets: permeability barriers and active efflux. Science 1994;264:382-8.

8 Nikaido H, Pagès JM. Broad-specificity efflux pumps and their role in multidrug resistance of Gram-negative bacteria. FEMS Microbiol Rev 2012;36:340-63.

9 Davin-Regli A, Bolla JM, James CE, Lavigne JP, Chevalier J, Garnotel E, et al. Membrane permeability and regulation of drug "influx and efflux" in enterobacterial pathogens. Curr Drug Targets 2008;9:750-9. 
10 Bolla JM, Alibert-Franco S, Handzlik J, Chevalier J, Mahamoud A, Boyer G, et al. Strategies for bypassing the membrane barrier in multidrug resistant Gram-negative bacteria. FEBS Lett 2011;585:1682-90.

11 Li XZ, Plésiat $P$, Nikaido $H$. The challenge of efflux-mediated antibiotic resistance in Gram-negative bacteria. Clin Microbiol Rev 2015;28:337-418.

12 Blair JM, Webber MA, Baylay AJ, Ogbolu DO, Piddock LJ. Molecular mechanisms of antibiotic resistance. Nat Rev Microbiol 2015;13:42-51.

13 Stavenger, RA, Winterhalter M. TRANSLOCATION project: how to get good drugs into bad bugs. Sci Transl Med 2014;6:228ed7.

14 Masi M, Réfrégiers M, Pos KM, Pagès JM. Mechanisms of envelope permeability and antibiotic influx/efflux in Gram negative bacteria. Nat Microbiol 2017;2:17001.

15 Krishnamoorthy G, Wolloscheck D, Weeks JW, Croft C, Rybenkov VV, Zgurskaya HI. Breaking the permeability Barrier of Escherichia coli by controlled hyperporination of the outer membrane. Antimicrob Agents Chemother. 2016;60:7372-81.

16 Zhou Y, Joubran C, Miller-Vedam L, Isabella V, Nayar A, Tentarelli S et al. Thinking outside the "bug": a unique assay to measure intracellular drug penetration in gram-negative bacteria. Anal Chem 2015 ;87 :3579-84.

17 Kaščáková S, Maigre L, Chevalier J, Réfrégiers M, Pagès JM. Antibiotic transport in resistant bacteria: synchrotron UV fluorescence microscopy to determine antibiotic accumulation with single cell resolution. PLoS ONE 2012;6:e38624. 
18 Pagès JM, Kascàkovà $S$, Maigre L, Allam A, Alimi M, Chevalier J, et al. New Peptide-based antimicrobials for tackling drug resistance in bacteria: single-cell fluorescence imaging. ACS Med Chem Lett 2013;4:556-9.

19 Koronakis V, Sharff A, Koronakis E, Luisi B, Hughes C. Crystal structure of the bacterial membrane protein TolC central to multidrug efflux and protein export. Nature 2000;405:914-9.

20 Symmons MF, Bokma E, Koronakis E, Hughes C, Koronakis V. The assembled structure of a complete tripartite bacterial multidrug efflux pump. Proc Natl Acad Sci U S A 2009;106:7173-8.

21 Du D, van Veen HW, Murakami S, Pos KM, Luisi BF. Structural and functional aspects of the multidrug efflux pump AcrB. Biol Chem 2009;390:693-9.

22 Pei XY, Hinchliffe P, Symmons MF, Koronakis E, Benz R, Hughes C, Koronakis V. Structures of sequential open states in a symmetrical opening transition of the TolC exit duct. Proc Natl Acad Sci U S A 2011;108:2112-7.

23 Hinchliffe P, Symmons MF, Hughes C, Koronakis V. Structure and operation of bacterial tripartite pumps. Annu Rev Microbiol 2013;67:221-42.

24 Yamaguchi A, Nakashima R, Sakurai K. Structural basis of RND-type multidrug exporters. Front Microbiol 2015;6:327.

25 Müller RT, Pos KM. The assembly and disassembly of the AcrAB-TolC three-component multidrug efflux pump. Biol Chem 2015;396:1083-9.

26 Daury L, Orange F, Taveau JC, Verchère A, Monlezun L, Gounou C, Marreddy RK, Picard M, Broutin I, Pos KM, Lambert O. Tripartite assembly of RND multidrug efflux pumps. Nat Commun 2016;7:10731. 
27 Du D, Wang Z, James NR, Voss JE, Klimont E, Ohene-Agyei T, Venter H, Chiu W, Luisi BF. Structure of the AcrAB-TolC multidrug efflux pump. Nature 2014;509:512-15.

28 Cohen SP, Hooper DC, Wolfson JS, Souza KS, McMurry LM, Levy SB. Endogenous active efflux of norfloxacin in susceptible Escherichia coli. Antimicrob Agents Chemother 1988;32:1187-91.

29 Cohen SP, McMurry LM, Hooper DC, Wolfson JS, Levy SB. Crossresistance to fluoroquinolones in multiple-antibiotic-resistant (Mar) Escherichia coli selected by tetracycline or chloramphenicol: decreased drug accumulation associated with membrane changes in addition to OmpF reduction. Antimicrob Agents Chemother 1989;33:1318-25.

30 Li XZ, Livermore DM, Nikaido $H$. Role of efflux pump(s) in intrinsic resistance of Pseudomonas aeruginosa: resistance to tetracycline, chloramphenicol, and norfloxacin Antimicrob Agents Chemother 1994;38:1732-41.

31 Ocaktan A, Yoneyama $\mathrm{H}$, Nakae T. Use of fluorescence probes to monitor function of the subunit proteins of the MexA-MexB-OprM drug extrusion machinery in Pseudomonas aeruginosa. J Biol Chem 1997;272:21964-9.

32 Germ M, Yoshihara E, Yoneyama H, Nakae T. Interplay between the efflux pump and the outer membrane permeability barrier in fluorescent dye accumulation in Pseudomonas aeruginosa. Biochem Biophys Res Commun 1999;261:452-5.

33 Martins $M$, Santos B, Martins A, Viveiros M, Couto I, Cruz A, et al. Management Committee Members; of Cost B16; European Commission/European Science Foundation. An instrument-free method for 
the demonstration of efflux pump activity of bacteria. In Vivo 2006;20:65764.

34 Martins A, Spengler G, Martins M, Rodrigues L, Viveiros M, Davin-Regli A, et al. Physiological characterisation of the efflux pump system of antibioticsusceptible and multidrug-resistant Enterobacter aerogenes. Int $\mathrm{J}$ Antimicrob Agents 2010;36:313-8.

35 Martins M, Viveiros M, Couto I, Costa SS, Pacheco T, Fanning S, et al. Identification of efflux pump-mediated multidrug-resistant bacteria by the ethidium bromide-agar cartwheel method. In Vivo 2011;25:171-8.

36 Martins M, McCusker MP, Viveiros M, Couto I, Fanning S, Pagès JM, et al. A simple method for assessment of MDR bacteria for over-expressed efflux pumps. Open Microbiol J 2013;7:72-82.

37 Viveiros M, Martins A, Paixão L, Rodrigues L, Martins M, Couto I, Fähnrich E, Kern WV, Amaral L. Demonstration of intrinsic efflux activity of Escherichia coli K-12 AG100 by an automated ethidium bromide method. Int J Antimicrob Agents 2008;31:458-62.

38 Bohnert JA, Karamian B, Nikaido H. Optimized Nile Red efflux assay of AcrAB-TolC multidrug efflux system shows competition between substrates. Antimicrob Agents Chemother 2010;54:3770-5.

39 Bohnert JA, Schuster S, Szymaniak-Vits M, Kern WV. Determination of real-time efflux phenotypes in Escherichia coli AcrB binding pocket phenylalanine mutants using a 1,2'-dinaphthylamine efflux assay. PLoS ONE 2011;6:e21196.

40 Bohnert JA, Schuster S, Kern WV, Karcz T, Olejarz A, Kaczor A, et al. Novel piperazine arylideneimidazolones inhibit the AcrAB-TolC pump in 
Escherichia coli and simultaneously act as fluorescent membrane probes in a combined real-time influx and efflux assay. Antimicrob Agents Chemother 2016;60:1974-83.

41 Husain $F$, Nikaido $\mathrm{H}$. Substrate path in the AcrB multidrug efflux pump of Escherichia coli. Mol Microbiol 2010;78:320-30.

42 Misra R, Morrison KD, Cho HJ, Khuu T. Importance of real-time assays to distinguish multidrug efflux pump inhibiting and outer membrane destabilizing activities in Escherichia coli. J Bacteriol 2015;197:2479-88.

43 Nagano K, Nikaido H. Kinetic behavior of the major multidrug efflux pump AcrB of Escherichia coli. Proc Natl Acad Sci U S A. 2009; 106:5854-5858.

44 Lim SP, Nikaido $\mathrm{H}$. Kinetic parameters of efflux of penicillins by the multidrug efflux transporter AcrAB-TolC of Escherichia coli. Antimicrob Agents Chemother. 2010; 54:1800-1806.

45 Kinana AD, Vargiu AV, May T, Nikaido H. Aminoacyl $\beta$-naphthylamides as substrates and modulators of AcrB multidrug efflux pump. Proc Natl Acad Sci U S A. 2016;113:1405-1410.

46 Hirai K, Aoyama H, Irikura T, lyobe S, Mitsuhashi S. Differences in susceptibility to quinolones of outer membrane mutants of Salmonella typhimurium and Escherichia coli. Antimicrob Agents Chemother 1986;29:535-8.

47 Hirai K, Suzue S, Irikura T, lyobe S, Mitsuhashi S. Mutations producing resistance to norfloxacin in Pseudomonas aeruginosa. Antimicrob Agents Chemother 1987;31:582-6.

48 Chapman JS, Georgopapadakou NH. Fluorometric assay for fleroxacin uptake by bacterial cells. Antimicrob Agents Chemother 1989;33:27-9. 
49 De Zeeuw JR. Accumulation of tetracyclines by Escherichia coli. J Bacteriol 1968;95:498-506.

50 Mortimer PG, Piddock LJ. A comparison of methods used for measuring the accumulation of quinolones by Enterobacteriaceae, Pseudomonas aeruginosa and Staphylococcus aureus. J Antimicrob Chemother 1991;28:639-53.

51 Chevalier J, Malléa M, Pagès JM. Comparative aspects of the diffusion of norfloxacin, cefepime and spermine through the $\mathrm{F}$ porin channel of Enterobacter cloacae. Biochem J 2000;348:223-7.

52 Baucheron S, Imberechts H, Chaslus-Dancla E, Cloeckaert A. The AcrB multidrug transporter plays a major role in high-level fluoroquinolone resistance in Salmonella enterica serovar typhimurium phage type DT204. Microb Drug Resist 2002; 8:281-9.

53 Yu EW, Aires JR, McDermott G, Nikaido H. A periplasmic drug-binding site of the AcrB multidrug efflux pump: a crystallographic and site-directed mutagenesis study. J Bacteriol 2005;187:6804-15.

54 Cinquin B, Maigre L, Pinet E, Chevalier J, Stavenger RA, Mills S, et al. Microspectrometric insights on the uptake of antibiotics at the single bacterial cell level. Sci Rep $2015 ; 5: 17968$.

55 Allam A, Maigre L, Vergalli J, Dumont E, Cinquin B, Alves de Sousa R, et al. Microspectrofluorimetry to dissect the permeation of ceftazidime in Gram-negative bacteria. Sci Rep 2017;7:986.

56 Zhao G, Meier TI, Kahl SD, Gee KR, Blaszczak LC. Bocillin FL, a sensitive and commercially available reagent for detection of penicillin-binding proteins. Antimicrob Agents Chemother 1999;43:1124-8. 
57 Pu Y, Zhao Z, Li Y, Zou J, Ma Q, Zhao Y, et al. Enhanced efflux activity facilitates drug tolerance in dormant bacterial cells. Mol Cell 2016;62:28494.

58 Cherkaoui A, Diene SM, Renzoni A, Emonet S, Renzi G, François P, et al. Imipenem heteroresistance in nontypeable Haemophilus influenzae is linked to a combination of altered PBP3, slow drug influx and direct efflux regulation. Clin Microbiol Infect 2017;23:118.e9-118.e19.

59 Vergalli J, Dumont E, Cinquin B, Maigre L, Pajovic J, Bacqué E, Mourez M, Réfrégiers M, Pagès JM. Fluoroquinolone structure and translocation flux across bacterial membrane. Sci Rep 2017;7:9821.

60 Pagès JM, Peslier S, Keating TA, Lavigne JP, Nichols WW. Role of the outer membrane and porins in susceptibility of $\beta$-lactamase-producing Enterobacteriaceae to ceftazidime-avibactam. Antimicrob Agents Chemother 2015;60:1349-59.

61 Nikaido $H$. Role of permeability barriers in resistance to B-lactams antibiotics. Pharmac Ther 1985;27:197-231.

62 Nikaido $\mathrm{H}$. Outer membrane barrier as a mechanism of antimicrobial resistance. Antimicrob Agents Chemother 1989;33:1831-6.

63 Zgurskaya HI, Nikaido H. Bypassing the periplasm: reconstitution of the AcrAB multidrug efflux pump of Escherichia coli. Proc Natl Acad Sci U S A. 1999;96:7190-5.

64 Picard $M$, Verchère $A$, Broutin I. Monitoring the active transport of efflux pumps after their reconstitution into proteoliposomes: caveats and keys. Anal Biochem 2012;420:194-6. 
65 Verchère A, Broutin I, Picard M. Photo-induced proton gradients for the in vitro investigation of bacterial efflux pumps. Sci Rep 2012;2:306.

66 Verchère $A$, Dezi $M$, Adrien V, Broutin I, Picard M. In vitro transport activity of the fully assembled MexAB-OprM efflux pump from Pseudomonas aeruginosa. Nat Commun 2015;6:6890.

67 Davis TD, Gerry CJ, Tan DS. General platform for systematic quantitative evaluation of small-molecule permeability in bacteria. ACS Chem Biol 2014;9:2535-44.

68 Brown AR, Ettefagh KA, Todd D, Cole PS, Egan JM, Foil DH, et al. A mass spectrometry-based assay for improved quantitative measurements of efflux pump inhibition. PLoS ONE 2015;10:e0124814.

69 Richter MF, Drown BS, Riley AP, Garcia A, Shirai T, Svec RL, et al. Predictive compound accumulation rules yield a broad-spectrum antibiotic. Nature 2017;545:299-304. 


\section{Legends for Figures}

Figure 1: Identification of efflux pump-mediated multidrug-resistant bacteria by the ethidium bromide-agar cartwheel method.

Left: Cartwheel pattern for the swabbing of the bacterial strains tested by the $\mathrm{EtBr}$ agar cartwheel method. Controls and clinical isolates were swabbed on an $\mathrm{EtBr}$ containing agar plate, according to the diagram.

Right: Example of the EtBr-agar cartwheel method applied to Enterobacter aerogenes strains on agar plates containing $1.5 \mathrm{mg} / \mathrm{l}$ of EtBr. Following overnight incubation at $37^{\circ} \mathrm{C}$ for 16 hours, fluorescence was detected under UV light. (from [34]).

Figure 2: Real-time efflux assay using fluorescent probes.

(A) Protocol of the real-time efflux method. The cells are preloaded with a dye which is fluorescent in nonpolar environments such as bacterial membranes. Addition of glucose energizes the efflux pump and triggers the dye efflux across the envelope, leading to the decrease of fluorescence.

(B) Representative 1,2'-DNA efflux curves of $E$. aerogenes EA289, a clinical isolate overexpressing AcrAB efflux pumps, and EA298 its tolC- derivative. Fluorescence of the $A c r A B$ overexpressing strain is decreasing while the fluorescence of the strain devoid of TolC is stable.

Figure 3: Determination of antibiotic concentration in bacteria using spectrofluorimetry. 
(A) Protocol of the spectrofluorimetry method: After incubation of bacteria with the antibiotic, bacteria cells are washed onto a sucrose cushion in order to avoid nonspecific adsorption on the cell surface. The cells are then lysed overnight and the fluorescence intensity of the intracellular content is measured.

(B) Representative fluorescence curves corresponding to the lysates of the overexpressing AcrAB efflux pump strain E. aerogenes EA289 and its tolC- derivative strain EA298, incubated with fleroxacin with or without CCCP.

Upper panel: kinetic of fleroxacin accumulation in the cells during $1 \mathrm{~h}$ of incubation.

Lower panel: Peaks of fluorescence (corresponding to the fleroxacin emission wavelength) of the lysates sampled at 15 minutes of incubation.

Figure 4: Fluoroquinolone time-course accumulation in individual bacterial cells using DUV microspectrofluorimetry.

(A) Average fluorescence intensity time course of 100 individual cells of the overexpressing AcrAB efflux pump strain E. aerogenes EA289 (solid line) and its tolC- derivative strain EA298 (dashed line) incubated with fleroxacin. (from [53]).

(B) Images taken by microscopy of isolated bacterium accumulating fleroxacin. (C) Antibacterial activities and spectral properties of fleroxacin. MIC (Minimal inhibitory concentration) are indicated in mg/L; PMBN (Polymyxin B nonapeptide) was used at $51.2 \mathrm{mg} / \mathrm{L}, \mathrm{PABN}$ (Phenylalanine-arginine-ß-naphthylamide) at $20 \mathrm{mg} / \mathrm{L}$ and $\mathrm{CCCP}$ (carbonyl cyanide m-chlorophenylhydrazone) at $10 \mu \mathrm{M}$. (D) Scheme of the translocation of fleroxacin (FLX) in a gram-negative bacterial cell. [FLX] ext: Concentration of fleroxacin in the external environment, $[F L X]_{p p}$ in the periplasmic space, $[F L X]_{\text {cyt }}$ in cytoplasm. 
Figure 5: Reconstitution of efflux pumps in proteoliposomes.

(A) Schematic representation of the MexA-MexB-OprM pump from Pseudomonas aeruginosa (Adapted from [64]).

(B) Cartoon representation of liposomes reconstituted with bacteriorhodopsin (BR) from Halobacter halobium (upper scheme) or with both $\mathrm{BR}$ and MexB were reconstituted in liposomes containing pyranine (lower scheme). BR is used to generate a photo-induced proton gradient to activate the MexB efflux pump. After illumination of the proteoliposomes, BR generates a transmembrane proton gradient, which is then used by MexB to transport a fluorescent dye. (C) Monitoring of the liposomal acidification upon illumination. Pyranine fluorescence variations, as a result of MexB efflux activity, were normalized to the corresponding $\mathrm{pH}$ variations based on titration of the fluorescence variation as a function of $\mathrm{pH}$. MexB is active only in the presence of the periplasmic adaptor MexA. 

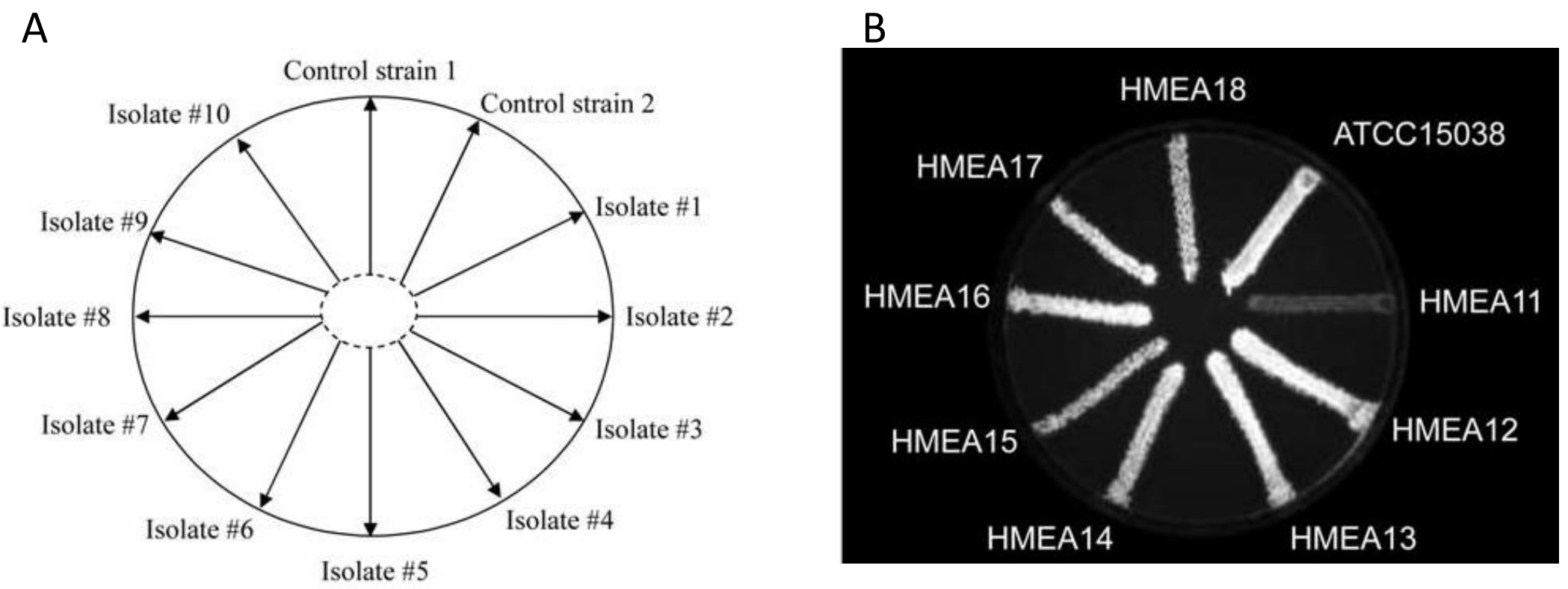
A

Overnight grown bacterial culture in rich medium

Step \# 1 Overnight accumulation of dye in minimal nutrient conditions

Spin down cells and resuspend in Mg-PPB to OD $\sim 0.25$

Add dye $\left[1,2^{\prime}-\mathrm{DNA}\right]=32 \mu \mathrm{M}$ and $[\mathrm{CCCP}]=5 \mu \mathrm{M}$ and incubate $\mathrm{o} / \mathrm{n}$ at $37^{\circ} \mathrm{C}$

\section{Step \# 2 Control dye accumulation}

Spin down cells, wash and transfer $100 \mu$ into wells of blackflat bottom 96 well half area microplates and read fluorescence $(370 / 421 \mathrm{~nm}$ excitation/emission)

\section{Step \# 3 Monitor dye efflux}

Add $5 \mu$ of $1 \mathrm{M}$ glucose and monitor fluorescence decrease for 5 minutes

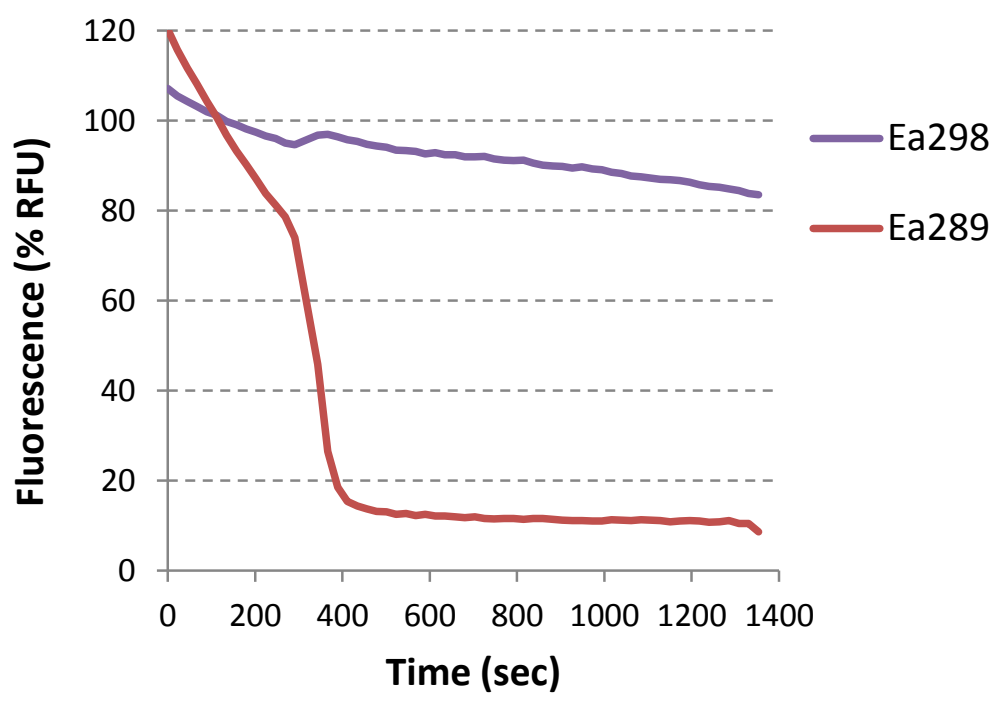


A

Bacterial culture $\left(\mathrm{OD}_{600} \sim 0.6\right)$

Spin down cells and resuspend in phosphate buffer to OD $\sim 6$

\section{Step \# 1 Antibiotic accumulation}

Add antibiotic $[F L X]=64 \mu \mathrm{g} / \mathrm{ml}$ ( $8 \times$ MIC of the most sensitive strain)

$$
\pm[\mathrm{CCCP}]=10 \mu \mathrm{M}
$$$$
\text { Incubate at } 37^{\circ} \mathrm{C}
$$

\section{Step \# 2 Stop accumulation and remove non-specific absorbance}

Spin down $400 \mu$ l of cells on top of $550 \mu$ l of $1 M$ sucrose solution

\section{Step \# 3 Cell lysis}

Add $500 \mu$ of $\mathrm{HCl}$-glycine $\mathrm{pH} 3$ Incubate $\mathrm{o} / \mathrm{n}$ at room temperature

\section{Step \# 4 Acquisition of fluorescence}

Spin down, transfer $100 \mu$ l of clear lysates into wells of flat bottom 96 well half area microplates and read fluorescence (283/451 nm excitation/emission)
B

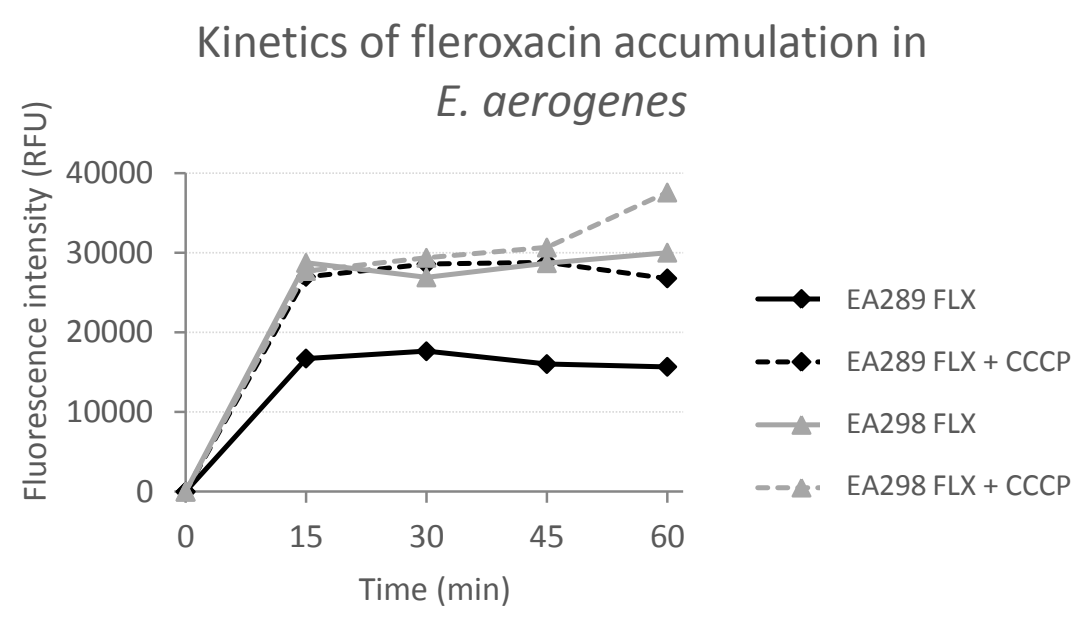

15 min accumulation of fleroxacin in E. aerogenes

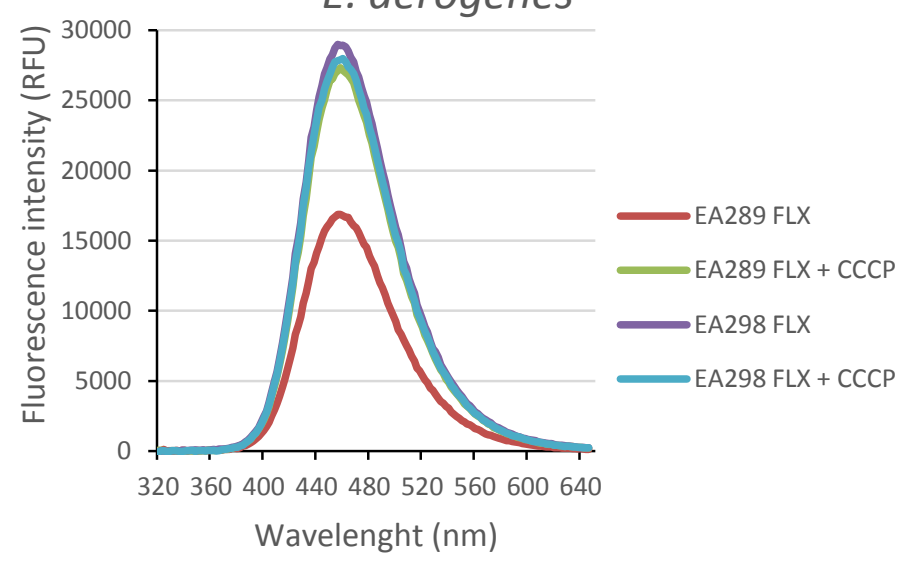


Figure4

A

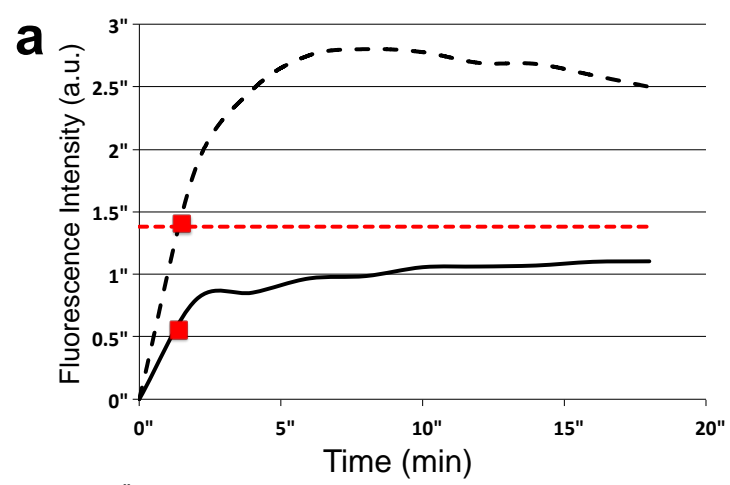

b $\underset{\text { 离 }}{4.5^{\prime \prime}}$

\begin{tabular}{|c|c|c|c|c|c|c|c|}
\hline \multicolumn{6}{|c|}{ MIC } & \multirow{2}{*}{\multicolumn{2}{|c|}{$\begin{array}{c}\text { Spectral properties } \\
\text { Wavelength }\end{array}$}} \\
\hline$\Phi_{2 "}$ & EA289 & & & EA298 & & & \\
\hline $\begin{array}{l}\text { 1.5"no } \\
\$_{1} \text { ad'ditive }\end{array}$ & $+\mathrm{PMBN}$ & $+P A \beta N$ & $\begin{array}{c}\text { no } \\
\text { additive }\end{array}$ & $+\mathrm{PMBN}$ & $+P A B N$ & excitation & emission \\
\hline o.5"64 & 64 & $32-16$ & 8 & 8 & 8 & $290 \mathrm{~nm}$ & $460 \mathrm{~nm}$ \\
\hline
\end{tabular}

$\begin{array}{lll}0^{\prime \prime} & & \\ 0 " & 5 " & 10 "\end{array}$

Time (min)
B

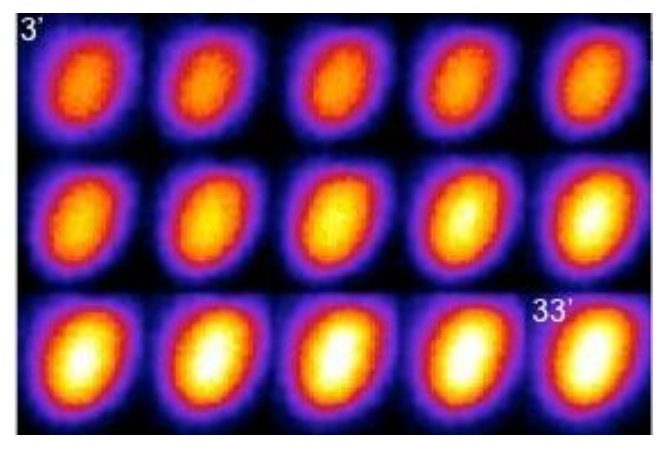

20"

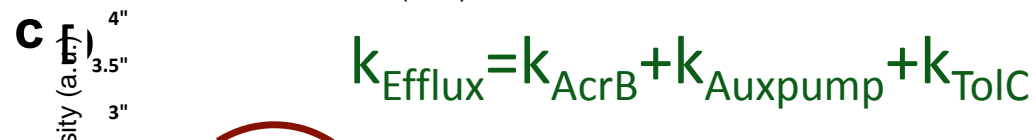

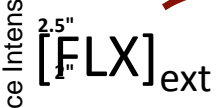

额 $1.5^{\prime \prime}$

ญे

은 $0.5^{\prime \prime}$

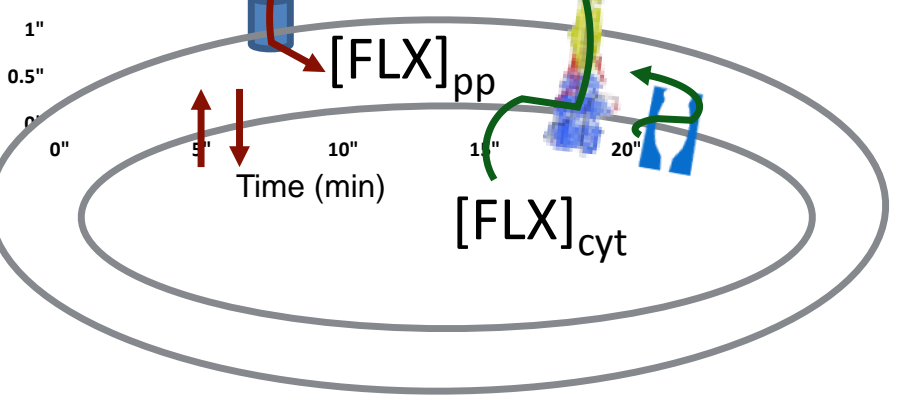


Figure5

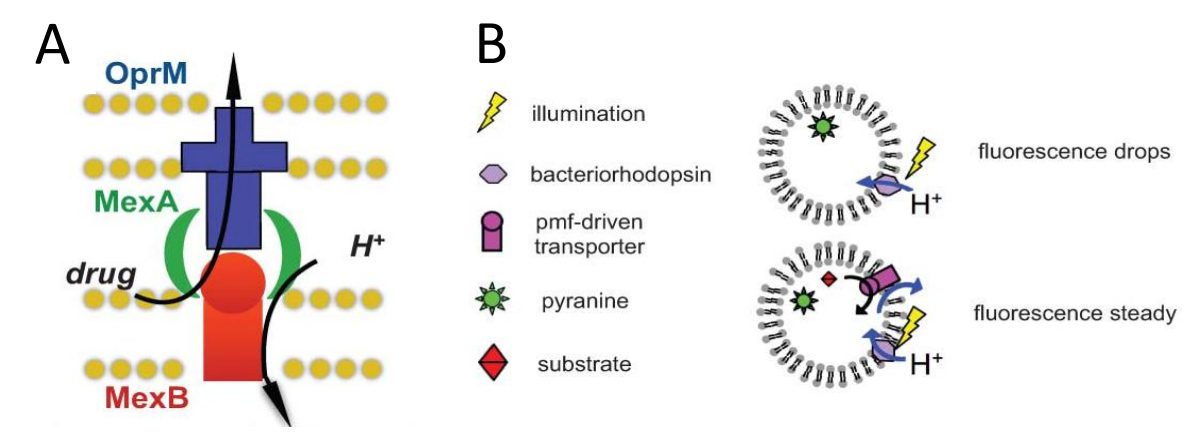

C

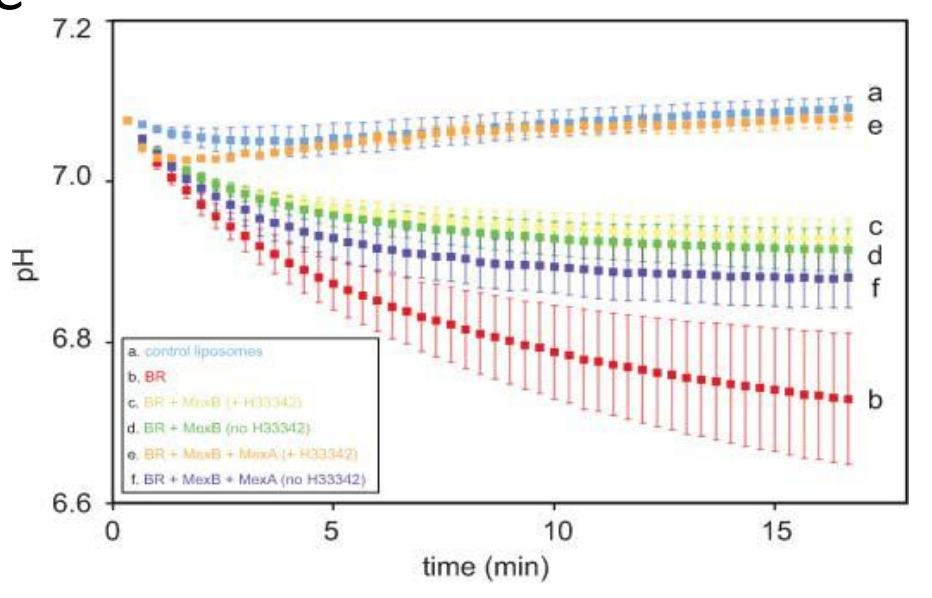




\section{Reviewers' comments and responses in blue}

Reviewer \#1: No comments

Reviewer \#2: The manuscript is now almost ready for acceptance. We thank the authors for addressing most of our questions. However, we point that the following 3 points are still missing:

point \#1

initial question:

L110: Indeed, crystal structures of the individual proteins have been determined but one should also acknowledge the recent EM data provided by Luisi and collaborators, as well as that of Lambert and collaborators, that brings light to the overall assembly of the pump.

response of the authors:

-> References to the work of Lambert and coll. and others have been added. Luisi and coll. solved MacAB-TolC, which belongs to another superfamily of efflux pumps.

point that still must be corrected:

>>> Ben Luisi and colleagues have recently solved the MacAB TolC but they have also described the AcrABTolC pump, see following paper : Du, D., Wang, Z., James, N.R., Voss, J.E., Klimont, E., Ohene-Agyei, T., Venter, H., Chiu, W., and Luisi, B.F. (2014). Structure of the AcrAB-TolC multidrug efflux pump. Nature 509, 512-515.

Thanks, this reference has been added.

point \#2

initial question:

L82-84: the authors never state why deep UV is mandatory compared to classical UV fluorescence.

responses of the authors:

-> The absorbance of quinolones molecules being maximum between 220 and 340 $\mathrm{nm}$ (depending of the molecule studied), classical UV fluorescence (below $470 \mathrm{~nm}$ ) cannot be used. This distinction is mandatory in microscopy were UV fluorescence microscopy is between 340 and $420 \mathrm{~nm}$ with a strong transmission drop below 350 $\mathrm{nm}$; however, in spectrometry, UV spectrometry would cover this range and the distinction is not necessary.

\& initial question:

L236: « It is absolutely required that the used molecule [...] exhibits a good penetration through the $\mathrm{OM}$ and $\mathrm{IM} \gg=>$ how is this routinely checked?

responses of the authors:

- > This is checked after incubating the molecule with efflux-minus cells or in the presence of CCCP.

\& initial question:

L310: How do the «CAZ fluorescent derivatives » differ from each other? 
responses of the authors:

-> Two fluorescent CAZ have been synthesized and used in this study. CAZ* is labelled with a coumarin and its fluorescent signal is not affected by cleavage by periplasmic <beta>-lactamases. Because we wanted to confirm the periplasmic localization of the translocated CAZ, CAZ ${ }^{* *}$ was synthesized. $C A Z^{* *}$ is labelled with methoxyquinoline but becomes fluorescent only upon cleavage by periplasmic $<$ beta>-lactamases.

point that still must be corrected:

>>> These explanations make perfect sense. We think that including them somehow in the final Ms would help the reader as they did help the reviewer !

This has been added in the new version.

point \#3

initial question:

L302: SICAR is certainly a very powerful and promising concept but a newcomer in the field would be interested to have a clear illustration of this concept. In particular the reader would be very interested to report how indeed "physicochemical drug properties connects to the efficacy of translocation », as suggested in the text. However, there is no such description in Figure 4 ! In addition Panel 4E, although described in the "Legends for Figures », L630-635, is not shown.

responses of the authors:

-> We now refer to Vergalli J, Dumont E, Cinquin B, Maigre L, Pajovic J, Bacqué E, Mourez M, Réfrégiers M, Pagès JM. Fluoroquinolone structure and translocation flux across bacterial membrane. Sci. Rep. 2017;7(1):9821. In this paper, we calculated SICAR(efflux) as the ratio of the accumulated antibiotic in Efflux minus to Efflux plus strains. Similar approach could be taken to calculate SICAR(influx).

point that still must be corrected:

>>> The reference Vergalli et al. indeed clarifies this point. However we still stress that Panel 4E is still lacking !

Sorry for this omission, This has been corrected. 
UMR_MD1

Transporteurs Membranaires, Chimiorésistance et Drug-Design

Jean-Marie PAGÈS

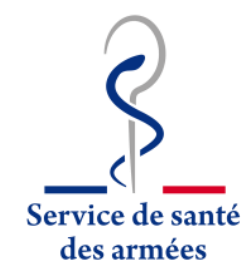

Marseille, November 22, 2017

Guest Editor

Research in Microbiology

Dear Pr. Klaas Martinus Pos

Please find enclosed the revised manuscript entitled ""Fluorescence enlightens the RND pump activity and the intra-bacterial concentration of antibiotics".

According to the comments, we have corrected the previous version. The responses to referee's points are included in the joined rebuttal document and I also include the annotated version describing the various modifications.

I hope that this new version will be well received by Editorial Board.

Sincerely yours,

Jean-Marie Pagès 
Fluorescence enlightens the RND pump activity and the intra-bacterial concentration of antibiotics

Muriel Masi ${ }^{\mathrm{a}}$, Estelle Dumont ${ }^{\mathrm{a}}$, Julia Vergalli ${ }^{\mathrm{a}}$, Jelena Pajovic ${ }^{\mathrm{b}, \mathrm{c}}$, Matthieu Réfrégiers ${ }^{\mathrm{b}}$, Jean-Marie Pagès ${ }^{\mathrm{a},}$

a UMR_MD1, Aix-Marseille Univ, IRBA, TMCD2, Facultés de Médecine et de Pharmacie, 27 bd Jean Moulin, 13385 Marseille cedex 05, France

b DISCO beamline, Synchrotron Soleil, L'Orme des Merisiers, Saint-Aubin BP 48, 91192 Gif-sur-Yvette cedex, France

c University of Belgrade, Faculty of Physics, Studentski trg 12, 11001 Belgrade, Serbia

muriel.masi@univ-amu.fr (M. Masi)

estelle.dumont@univ-amu.fr (E. Dumont)

julia.vergalli@univ-amu.fr (J. Vergalli)

unedogled@gmail.com (J. Pajovic)

matthieu.refregiers@synchrotron-soleil.fr (M. Réfrégiers)

jean-marie.pages@univ-amu.fr (J.M. Pagès) *Correspondence and reprints 


\section{Abstract}

To understand the antibiotic resistance in Gram-negative bacteria, a key point is to investigate antibiotic accumulation which is defined by influx and efflux. Several methods exist to evaluate the membrane permeability and efflux pump activity but they present some disadvantages and limitations. An optimized spectrofluorimetric method using the intrinsic tryptophan fluorescence as internal standard as well as a complementary microfluorimetric assay following the time-course accumulation in intact individual cells have been developed. Comparing the latter population and single cell approaches can lead to the understanding of the phenotypic heterogeneity within a population. The two methodologies lead to the determination of parameters, concentration, accumulation rates, localization that contribute to emerging concepts (RTC2T, SICAR) with the aim to identify and detail the antibiotic chemotypes that are involved in influx/efflux.

\section{Keywords}

Antibiotic; bacterial imaging; drug efflux pumps; Gram-negative bacteria; multidrug resistance; transporters 


\section{Introduction}

For several years antibiotic resistance has been an increasing threat to public health, it now concerns all major bacterial pathogens and antibiotic classes. A key challenge in antibiotic therapy is to determine the parameters modulating the in cellulo drug concentration required for a therapeutic action [1-3]. In Gram-negative antibacterial research, the concern is to evaluate the antibiotic permeation across the outer and inner membranes that constitute the bacterial envelope [4-6]. Translocation through the membrane barriers to reach the inhibitory concentration inside the bacterium is a pivotal step for antibacterial molecules [7-12].

The discovery and the development of new antimicrobials mostly rely on their capacity to reach critical concentrations $\left(\mathrm{C}_{\text {inh }}\right)$ at the vicinity of their intracellular target $[13,14]$. Despite several decades of studies focused on antibiotic activity against bacterial cells using different approaches, no consensus for the analysis of the kinetics and accumulation of antibacterial agents in individual bacterium and in bacterial populations exists to understand the drug translocation into living bacteria as a first step of drug action [15]. Currently the lack of appropriate assays is a substantial bottleneck for the optimization of new molecules regarding permeability and to increase antimicrobial activity in intact bacterial cells. TRANSLOCATION consortium supports the development of reliable and robust methods to quantify penetration and efflux processes in Gram-negative bacteria (see "TRANSLOCATION Project: www.imi.europa.eu/content/translocation; [13]).

Several methods and protocols have been developed in order to quantify and visualize the intra-bacterial concentrations of antibiotics and the role of membrane- 
associated mechanisms of resistance in the accumulation of antibacterial drugs (Influx, Efflux). Studies performed during this last decade have increased our understanding of how individual bacterial cells and bacterial populations control the internal concentration of antibiotics by using appropriate transport systems. In addition, original ways are now available to investigate in depth the drug translocation across bacterial membranes. Mass spectrometry appears as a promising method to determine the intracellular accumulation of label-free compounds $[14,16]$. Ultimately, this approach might help to characterize the permeability of various potential drugs, quantify antibiotic accumulation and meet the requirements of high throughput structure-activity relationship programs. In the case of naturally fluorescent drugs, intracellular accumulation can be monitored using a deep ultraviolet (DUV) light source that allows the detection by microspectrofluorimetry $[17,18]$. For example, fluoroquinolone antibiotics contain a quantum-yield of fluorescence sufficient to monitor their accumulation and localization in bacterial cells without requiring any addition of external probe.

The information obtained by using these new approaches, combined with the knowledge inherited from more traditional approaches, are critical for our understanding of drug transport and have implications for future strategies and for designing new drugs to combat antibiotic resistance.

Therefore, it is important to provide a recent and thoughtful perspective to the community that discusses the recent methods available for studying antibiotic penetration and correlation to antibacterial activities. From these studies and others, a new perspective emerges on how to capture and correlate the modes of action and kinetics of antibiotic uptake inside bacterial cells. 


\section{Detection of efflux activity}

The tripartite RND efflux pump family is well conserved in clinically relevant Enterobacteriaceae such as Escherichia coli, Enterobacter and Klebsiella spp, Salmonella enterica, as well as in other Gram-negative pathogens like Acinetobacter baumannii, Neisseria gonorrhoeae, and Pseudomonas aeruginosa [8,12].

Based on its broad range substrate selectivity and its high expression level in clinical resistant isolates, it is a major contributor to the MDR resistance in these species. The archetypal E. coli AcrAB-TolC (or MexAB-OprM in P. aeruginosa) is the best structurally characterized RND efflux complex, since the crystal structures of the individual AcrA, AcrB and TolC have been solved and assembled complexes have been proposed [19-26].27]. While structural models and dynamic simulations are relatively well advanced (see accompanying reviews in this special issue), the characterization of AcrAB-TolC (as well as other efflux pumps) from mechanistic and kinetic point of view remains mainly partial as it relies on the comparison of minimal inhibitory concentration (MIC) values between of wild-type and acrAB-tolC deleted strains.

\section{The radiolabeled assay}

The first assay developed to evaluate the efflux activity in bacterial cells was the measurement of radiolabeled drug accumulation in resistant strains [28-30]. The efflux activity was demonstrated in several MDR isolates by using CCCP or other poisons that collapse the energy component of the efflux, and consequently block the 
pump and restored the intracellular antibiotic concentration at a level similar to the normal susceptible reference strains. The radiolabeled assay presents some advantages about precision, sharpness of quantification but also large disadvantages regarding the availability/production of marked molecules, safety protocols, internal controls, low spatial resolution and waste treatments.

\section{The ethidium bromide-agar based method}

The accumulation of ethidium bromide ( $\mathrm{EtBr}$ ) was used to follow the activity of efflux pump in various bacterial species [31,32]. Later, a simple and instrument-free method that uses agar plates containing increasing concentrations of EtBr, as a fluorescent efflux pump substrate, has been developed to detect the presence of active efflux in swabbed strains [33]. This method, called the EtBr-agar cartwheel method, has been validated to identify overexpression of efflux pumps that contribute to MDR phenotypes in collections of clinical strains [34-37]. Briefly, it is based on that the minimal concentration of $\mathrm{EtBr}(\mathrm{MEB})$ in agar that produces fluorescence associated to bacteria growing at the surface of the agar defines the maximum extrusion rate of this substrate. Data showed that the MEB of strains that overexpress efflux pumps is considerably higher than that of reference strains. An example of results applied to one reference (ATCC15038) and eight MDR strains of E. aerogenes is shown: $E$. aerogenes HMEA11 showed no fluorescence at $1.5 \mu \mathrm{g} / \mathrm{ml}$ EtBr whereas the others including ATCC15038 fluoresced at $0.05 \mu \mathrm{g} / \mathrm{ml} \mathrm{EtBr}$ (Figure 1).

The main disadvantage of this method is the toxicity of the used dye, EtBr, the corresponding safety protocols require during the assays and the waste treatments of plates, effluents, etc. Moreover, like other dyes, $\mathrm{EtBr}$ is not per se an antibiotic and it 
is difficult to correlate an internal concentration, to an antibiotic activity and a clinical relevance.

\section{The semi-automated "real-time" method using fluorescent probes}

It was necessary to develop fast, easy-to-perform and reliable methods in order to study the real-time efflux of a pre-accumulated compound in bacteria expressing various efflux pumps.

Automated methods are advantageous in that they allow quantification of influx and efflux levels on a real-time basis and can be set up for medium throughput analysis of bacterial strains. The readability and reliability of this approach requires (i) that the chosen molecule does not alter bacterial metabolic functions at the working ranges, exhibits a good penetration through the outer membrane (and inner membrane), is a substrate of efflux pumps and yields high signal only when inside the cells and (ii) a protocol that detects the variation of this signal when molecules are expelled by the efflux activity.

Several fluorescent probes for which the spectroscopic properties change upon entering the cells are particularly appropriate for these assays: the bacterial cells can be preloaded with these dyes before triggering the efflux by adding an energy source. Two lipophilic compounds, Nile Red and 1,2'-dinaphthylamine(1,2'-DNA) that give negligible fluorescence in aqueous solutions but become strongly fluorescent in nonpolar environments such as bacterial membranes, have been described for measuring the efflux activity and the effect of putative efflux pump inhibitors [38-41]. After loading, cells are then energized by the addition of glucose, which produces the proton motive force in the inner membrane, energizes the RND pump and triggers the dye efflux across the envelope (Fig. 2). However, special attention should also be 
given to the self-quenching of the dye fluorescence in case of high concentration close to the bacterial membranes or to the quenching induced by other chemicals (e.g. efflux pump blockers/inhibitors) used in combination. In addition, similarly to $\mathrm{EtBr}$, these molecules are not antibiotics and the correlation between internal concentrations and antibacterial activities are not possible. Moreover, an internal standard is required to efficiently compare the data obtained in various bacterial series. The efflux activity was demonstrated in several MDR isolates by using CCCP or other poisons that collapse the energy component of the efflux, and consequently block the pump and restore the intracellular antibiotic concentration at a level similar to the normal susceptible reference strains. Interestingly, this approach can also be used to screen for molecules that inhibit efflux [40,42].

\section{Monitoring $\beta$-lactam efflux using rates of $\beta$-lactamase-mediated hydrolysis}

The knowledge of the kinetic behavior of efflux pumps is essential in our attempts to understand and quantify their contribution to antibiotic resistance. No success was achieved until the Nikaido laboratory determined the kinetic constants for several $\beta$ lactams, including penicillins and cephalosporins, in intact cells of E. coli [43-45]. First, the intracellular concentration of $\beta$-lactams, which accumulate in the periplasm, was calculated by from their hydrolysis rate by periplasmic $\beta$-lactamases. Then, the rate of efflux was calculated as the difference between the calculated rate of influx and the measured rate of hydrolysis. Results obtained with nitrocefin - a chromogenic cephalosporin - showed a $K_{\mathrm{m}}$ of about $5 \mu \mathrm{M}$ and a $V_{\max }$ around 0.025 $\mathrm{nmol} / \mathrm{mg} / \mathrm{s}$, which correspond to a $k_{\mathrm{cat}} \approx 10 / \mathrm{s}$ based on the cellular content of AcrB. Overall, penicillins present a stronger apparent affinity $(\approx 1 \mu \mathrm{M})$ for AcrB than cephalosporins (ranging from 5 to $300 \mu \mathrm{M}$ ). In contrast to nitrocefin, the other 
cephalosporins had higher values of $K_{\mathrm{m}}(\approx 20 \mu \mathrm{M}$ for cefamandole, $\approx 90 \mu \mathrm{M}$ for cephalotin, $\approx 300 \mu \mathrm{M}$ for cephaloridine). Interestingly, this study showed that low affinity substrates such as cephaloridine are pumped out very efficiently ( $k_{\text {cat }} \approx 290 /$ s) when the periplasmic concentration exceeds $100 \mu \mathrm{M}$, which is far superior to the MIC for this antibiotic $(\approx 0.5 \mu \mathrm{M})$. This finding pointed that efflux is not that important as long as it occurs in the range of intracellular concentration superior to the MIC.

\section{Determination of antibiotic accumulation in bacteria using UV fluorescence microscopy/spectroscopy methods}

Membrane-associated mechanisms of bacterial MDR (i.e. membrane impermeability and drug efflux) act to efficiently limit the concentration of antibiotics at the vicinity of their targets. Therefore, a key point in the understanding of these mechanisms is to determine and compare the intracellular concentration of antibiotics in bacterial cells accordingly to their phenotypic and genotypic status. Several approaches have been developed in the past by using plate assays $[46,47]$ and fluorimetry [48], mainly for measuring the accumulation of tetracyclines and fluoroquinolones by Enterobacteriaceae as reported previously $[49,50]$.

Quinolones are powerful antibiotics that inhibit the activity of DNA gyrase and topoisomerase IV enzymes located in the cytoplasm. The ability of quinolones to pass the bacterial membranes to reach their intracellular targets is a key factor for their activity. In Gram-negative bacteria, fluoroquinolones have been shown to use the outer membrane porins [51] to efficiently accumulate inside the cell. The mechanism of permeation across the inner membrane is less clear, but most likely involves an energy-independent passive diffusion mechanism. Moreover, quinolones are also excellent substrates of efflux pumps [52,53]. 
In 1989, Chapman \& Georgopapadakou have developed a fluorimetric method based on the natural fluorescence of the quinolone nucleus present in fluoroquinolones such as the clinically used ciprofloxacin and norfloxacin [48]. Several adaptations have improved the spectrofluorimetry of cell lysates and allow a precise quantification of the antibiotic content (in $\mathrm{ng} /$ bacterial cell) in a given bacterial cell using a calibration curve. Various publications report the determination of fluoroquinolone concentration in various bacterial species [14].

An optimized method to determine the fleroxacin accumulation inside Enterobacter aerogenes resistant strains that overproduced AcrAB-TolC efflux pump has been recently reported [17]. After incubation, the bacterial cells are washed onto a sucrose cushion in order to overcome problems of reproducibility mainly caused by nonspecific adsorption of antibiotic molecules at the bacterial surface [17]. Moreover, special attention has be given to the spectral properties of the fluorescent molecule (fleroxacin, ciprofloxacin) in order to monitor its fluorescence signal in bacterial lysates and to integrate an internal fluorescence standard, the intrinsic tryptophan fluorescence, in the protocol $[17,54]$. These special improvements have allowed generating comparative assays between various bacterial strains and species $[18,54,55]$. Furthermore, this internal standard that insures the quantitative valuation of various drugs/antibiotics on different bacterial strains is necessary for a comparative validation of other methods (such as mass spectrometry) for which no intrinsic standard has been selected yet.

About $E$. aerogenes and $E$. coli strains, the data indicate that the steady-state accumulation was stable after an incubation time of 10-15 minutes for the strains without AcrAB or overproducing the efflux pump. The CCCP addition during the 
assay with AcrAB overproducer strain restores the accumulation plateau observed in the acr $A B$ deleted strain (Fig. 3). To reach the best validation and robustness interval of this approach it is absolutely required that the used molecule (i) does not kill the bacteria at the used concentration during the incubation times, a parameter which can be checked by survival assays, (ii) exhibits a good penetration through the outer membrane (and inner membrane), (iii) is a substrate of efflux pumps as documented by the susceptibility determined in isogenic strains in parallel, and by using effluxdeleted cells or incubation in the presence of CCCP [17], and (iv) importantly cause non-overlapping signal with the intrinsic internal standard (e.g. tryptophan signal). Moreover, the signal must be detected in intact bacterial cell (microspectrofluorimetry) and in bacterial lysates by using the same antibiotic concentration and generate significant variation when molecules are expelled by the efflux activity. Interestingly, this method has indicated some discrepancy in the fluoroquinolone accumulation in a bacteria population issued from the same resistant strain treated with the ionophore suggesting some phenotypic heterogeneity [17].

Combining population and single cell approaches guarantee that, if several subpopulations with extreme behavior were present, they would not be underestimated.

It can be noted that a fluorescent B-lactam derivative has been recently used to study the antibiotic accumulation and susceptibility in bacterial persisters, a subpopulation dormant bacteria showing high level of tolerance to antibiotics [56]. Bocillin is a penicillin $\mathrm{V}$ molecule coupled to a fluorescein core, BODIPY FL dye (which is spectrally similar to fluorescein). This compound has been assayed to measure the activity of efflux pump on its intra-bacterial accumulation [57]. Interestingly, the authors reported that the internal accumulation of bocillin was 
significantly reduced in persisters due to the efflux activity of AcrAB-TolC pump [57]. Bocillin was also used for evaluating the role of efflux pump in the resistance of nontypeable Haemophilus influenzae [58]. Although this fluorescent penicillin derivative is an interesting tool, it must be mentioned that due to the involvement of porin channel during the uptake of this antibiotic family, an alteration of porin characteristics (expression level, porin type or channel conductance) can change the accumulation rate and consequently can perturb the determination of efflux activity $[6,8]$.

Fluoroquinolone time-course accumulation in a single bacterial cell using UV fluorescence microscopy, microfluorimetric assay

Optimized spectrofluorimetric and microscopic methods using appropriate calibration curves and internal standards have been developed to monitor the accumulation of fluoroquinolones in Enterobacteriaceae. More recently, these approaches have been modified for the measurement of antibiotic accumulation in intact individual cells: briefly the bacterial cells are deposited between two quartz coverslips and analysed by DUV microspectrofluorimetry and/or by DUV fluorescence imaging (Fig. 4). The cell viability was checked during the time exposure. With this protocol, the time-course of accumulation of selected fluoroquinolones can be recorded in different individual cells [54] and with various incubation conditions (antibiotic concentration, efflux blocker, etc). The rate of accumulation and the plateau reached after long time of incubation can be extracted for a given antibiotic and for a given strain [54].

These technologies will offer the opportunity to determine influx and efflux parameters such as the intracellular concentration of antibiotics $\left(C_{i n}\right)$, the critical 
inhibitory intracellular concentration of antibiotics $\left(\mathrm{C}_{\mathrm{inh}}\right)$, the precise contribution of limiting factors in reaching a $\mathrm{C}_{\text {inh }}$ (e.g. porins and efflux pumps) and the influence of chemical moieties (pharmacophores) within a specific class of antibiotic. The "Resident Time Concentration Close to Target" (RTC2T) concept includes the precise determination of both $\mathrm{C}_{\text {in }}$, and $\mathrm{C}_{\text {inh }}$ for a given antibacterial molecule for a given bacterial strain [14]. It will be useful to quantify the biological activity of different adjuvants in increasing the intracellular concentration of specific antibiotics in strains exhibiting membrane-associated mechanisms of resistance. The translocation of antibiotics belonging to different classes through bacterial membranes via outer membrane pores or transporters (porins or efflux pumps) is a relatively fast event and the steady-state concentrations are generally reached after short incubation times. Monitoring real-time accumulation of different quinolones showed different accumulation kinetics and steady-state accumulation levels depending on the properties (chemical and structural) of the compound in a selected bacterial background. From these observations a new concept, "Structure Intracellular Concentration Activity Relationship" (SICAR) can be elaborated to dissect the profile of antibacterial molecules [14]. SICAR connects the physicochemical drug properties to the efficacy of translocation through the bacterial membrane and the resulting intracellular accumulation [59].

These concepts have been recently used to dissect the role of chemical structures and the bacterial elements which are involved in influx (uptake) or in efflux, and guide rationale pharmacomodulation of side chains to fine-tune molecular interactions with membrane transporters. Two cases have been studied so far: an antibiotic having a periplasmic target and one having a cytoplasmic target, this gives the possibility to integrate the aspect about the cellular location. 
Ceftazidime (CAZ) is a potent cephalosporin to treat resistant bacteria in combination with B-lactamase inhibitors [60]. Different fluorescent derivatives have been synthesized to dissect the early step of translocation across bacterial outer membrane: $\mathrm{CAZ}^{*}$ is labeled with a coumarin and its fluorescent signal is not affected by cleavage by periplasmic B-lactamases, and $C A Z^{* *}$ is labeled with methoxyquinoline but becomes fluorescent only upon cleavage by periplasmic Blactamases [55]. The measure of internal accumulation and activities are performed on clinical resistant strains expressing various levels of porins and B-lactamases. By using microspectrofluorimetry and epifluorimetry, the translocation of CAZ to the periplasmic space was followed when the outer membrane barrier was permeabilized [55]. This study demonstrated the relationship between periplasmic accumulation and antibiotic activity by approaching B-lactam permeation relative to membrane permeability. Moreover, a correlation between internal accumulation and B-lactamase activity was provided that supports the pioneer model proposed by $\mathrm{H}$. Nikaido to explain the interplay existing between the membrane and enzymatic barrier for Blactams $[61,62]$.

Three selected fluoroquinolones have been studied for their accumulation in bacterial population and inside individual Gram-negative bacterial cells that express various levels of efflux pumps. For a given fluoroquinolone library, these assays allowed the determination of $\operatorname{SICAR}^{\mathrm{IN}}$ and $\operatorname{SICAR}^{\mathrm{EF}}$ indexes, the first one reflects "structure-to-penetration" relationships and the second one illustrates the correlation "structure-to-efflux". This original approach validates the SICAR concept $[14,59]$ and demonstrates the expected benefit by evidencing some pharmacophoric groups that can be involved in the penetration and in the efflux. 


\section{Reconstitution of efflux pumps in proteoliposomes}

Active drug transport by efflux pumps has also been investigated after reconstitution of purified proteins into proteoliposomes. A major difficulty is to generate quantitatively measurable and reproducible proton gradient across the liposome membrane. Primary in vitro transport assay has been designed by the Nikaido laboratory, in which reconstituted E. coli AcrB were energized by a proton gradient generated by the addition of valinomycin, a potassium-ionophore [63]. Detection of proton transport was monitored using pyranine, a lipophilic and $\mathrm{pH}$ dependent fluorescent probe. However, the stability of the valinomycin-generated $\Delta \mathrm{pH}$ was strongly influenced by the batches of lipids used for reconstitution and other factors [64]. To overcome this problem, Picard and colleagues have developed an original system in which they used bacteriorhodopsin (BR) from Halobacter halobium to generate a photo-induced proton gradient to activate the MexB efflux pump from $P$. aeruginosa [65]. In this system, BR, MexA and MexB were reconstituted in liposomes containing pyranine. After illumination of the proteoliposomes, BR generates a transmembrane proton gradient, which is then used by MexB to transport a fluorescent dye (Hoechst 33342). In this assay, pyranine fluorescence is monitored while the proton gradient is generated or dissipated as a result of MexB efflux activity (Fig. 5). Curves show that MexB is active only in the presence of the periplasmic adaptor MexA. Recently, significant improvements of this method have been made by combining proteoliposomes containing the MexAB and OprM portions of the complex. This allowed monitoring of transport by the tripartite MexAB-OprM pump in a system that mimics the dual-membrane architecture of Gram-negative bacteria $[26,66]$. 


\section{Conclusion}

Today with the development of DUV-fluorimetry method and apparatus, new tools have been proposed for studying the drug translocation across biological membrane and in living cells including bacterial population and individual bacterial cells.

Boosted by emerging and upgraded methodologies (detector, filters, etc), new concepts such as "Structure Intracellular Concentration Activity Relationship" (SICAR) and "Resident Time Concentration Close to Target" (RTC2T), have been proposed in order to bridge the molecular and membrane transport aspects [14]. Using RTC2T and SICAR methodologies, a new dissection of antibiotic translocationtransport can be defined to better understand and improve the antibiotic chemotypes that are related to permeation and efflux. The final objective will be to enhance the antibacterial efficacy of a rationally synthetized antibiotic against a resistant species.

A second important aspect is the complex relation integrating "kinetics/localization/concentration" inside the bacterial cell and the effect on bacterial metabolism and cell life. An important step is to correlate the intracellular concentration threshold and antibacterial activity for the antibiotic molecule and also for new "adjuvants" that can improve the antibiotic concentration inside the bacterium.

Conclusively, the use of this methodology that measures the real-time accumulation in different bacterial phenotypes and takes into account various chemical structures, allows analyzing the molecular bases of drug translocation. Consequently, the concept of "structure intracellular concentration activity 
relationship" previously proposed [14] can be extensively studied for fluorescent antibiotics. Regarding non-fluorescent molecules, a competitive assay can be designed to indirectly measure these parameters, or alternatively mass spectrometry quantification can be successfully applied [67-69]. About mass spectrometry, the precision of the method asks for a robust internal standard that could be used to standardize the assays carried out with various bacterial species and various strains including clinical isolates.

By using these methods available in microplates, the role of chemical side chains involved in the membrane permeation or in the efflux transport [59] can be dissected to better design drug side chains fitting well with the translocation constraints.

The future step will be the development of microfluidic-microfluorimetric approach that detect two events in the same bacterial cell, influx and efflux. This detection, should finally allow the discrimination inside the population of susceptible (fluorescence signal) and low-susceptible (no signal) individual bacteria present under specific conditions. This multiplexed approach paves the way for studying the diversity in the population, the presence of persisters, and the role of membraneassociated mechanisms of resistance in the bacterial response face to the antibiotic stimulus. 


\section{Conflict of interest}

No conflict

\section{Acknowledgements}

We thank Anne Davin-Regli, Robert Stavenger and Mathias Winterhalter for their fruitful discussions.

The research leading to the discussions presented here was conducted as part of the TRANSLOCATION consortium and has received support from the Innovative Medicines Initiatives Joint Undertaking under Grant Agreement $\mathrm{n}^{\circ} 115525$, resources which are composed of financial contribution from the European Union's seventh framework program (FP7/2007-2013) and EFPIA companies in kind contribution.

This work was also supported by Aix-Marseille Univ. and Service de Santé des Armées, and by Soleil program. 


\section{References}

1 Jones D. News and analysis: the antibacterial lead discovery challenge. Nat RevDrug Discov 2010;9:751-2.

2 Watkins RR, Bonomo R. A. Overview: global and local impact of antibiotic resistance. Infect Dis Clin North Am 2016;30:313-22.

3 Laxminarayan R, Matsoso P, Pant S, Brower C, Røttingen JA, Klugman K, et al. Access to effective antimicrobials: a worldwide challenge. Lancet 2016;387:168-75.

4 Nikaido $\mathrm{H}$. Molecular basis of bacterial outer membrane permeability revisited. Microbiol Mol Biol Rev 2003;67:593-656.

5 Zgurskaya HI, López CA, Gnanakaran S. Permeability barrier of Gramnegative cell envelopes and approaches to bypass it. ACS Infect Dis $2015 ; 1: 512-522$.

6 Pagès JM, James $C E$, Winterhalter $M$. The porin and the permeating antibiotic: a selective diffusion barrier in Gram-negative bacteria. Nat Rev Microbiol 2008;6:893-903.

7 Nikaido $\mathrm{H}$. Prevention of drug access to bacterial targets: permeability barriers and active efflux. Science 1994;264:382-8.

8 Nikaido H, Pagès JM. Broad-specificity efflux pumps and their role in multidrug resistance of Gram-negative bacteria. FEMS Microbiol Rev 2012;36:340-63.

9 Davin-Regli A, Bolla JM, James CE, Lavigne JP, Chevalier J, Garnotel E, et al. Membrane permeability and regulation of drug "influx and efflux" in enterobacterial pathogens. Curr Drug Targets 2008;9:750-9. 
10 Bolla JM, Alibert-Franco S, Handzlik J, Chevalier J, Mahamoud A, Boyer G, et al. Strategies for bypassing the membrane barrier in multidrug resistant Gram-negative bacteria. FEBS Lett 2011;585:1682-90.

11 Li XZ, Plésiat $P$, Nikaido $H$. The challenge of efflux-mediated antibiotic resistance in Gram-negative bacteria. Clin Microbiol Rev 2015;28:337-418.

12 Blair JM, Webber MA, Baylay AJ, Ogbolu DO, Piddock LJ. Molecular mechanisms of antibiotic resistance. Nat Rev Microbiol 2015;13:42-51.

13 Stavenger, RA, Winterhalter M. TRANSLOCATION project: how to get good drugs into bad bugs. Sci Transl Med 2014;6:228ed7.

14 Masi M, Réfrégiers M, Pos KM, Pagès JM. Mechanisms of envelope permeability and antibiotic influx/efflux in Gram negative bacteria. Nat Microbiol 2017;2:17001.

15 Krishnamoorthy G, Wolloscheck D, Weeks JW, Croft C, Rybenkov VV, Zgurskaya HI. Breaking the permeability Barrier of Escherichia coli by controlled hyperporination of the outer membrane. Antimicrob Agents Chemother. 2016;60:7372-81.

16 Zhou Y, Joubran C, Miller-Vedam L, Isabella V, Nayar A, Tentarelli S et al. Thinking outside the "bug": a unique assay to measure intracellular drug penetration in gram-negative bacteria. Anal Chem 2015 ;87 :3579-84.

17 Kaščáková S, Maigre L, Chevalier J, Réfrégiers M, Pagès JM. Antibiotic transport in resistant bacteria: synchrotron UV fluorescence microscopy to determine antibiotic accumulation with single cell resolution. PLoS ONE 2012;6:e38624. 
18 Pagès JM, Kascàkovà $S$, Maigre L, Allam A, Alimi M, Chevalier J, et al. New Peptide-based antimicrobials for tackling drug resistance in bacteria: single-cell fluorescence imaging. ACS Med Chem Lett 2013;4:556-9.

19 Koronakis V, Sharff A, Koronakis E, Luisi B, Hughes C. Crystal structure of the bacterial membrane protein TolC central to multidrug efflux and protein export. Nature 2000;405:914-9.

20 Symmons MF, Bokma E, Koronakis E, Hughes C, Koronakis V. The assembled structure of a complete tripartite bacterial multidrug efflux pump. Proc Natl Acad Sci U S A 2009;106:7173-8.

21 Du D, van Veen HW, Murakami S, Pos KM, Luisi BF. Structural and functional aspects of the multidrug efflux pump AcrB. Biol Chem 2009;390:693-9.

22 Pei XY, Hinchliffe P, Symmons MF, Koronakis E, Benz R, Hughes C, Koronakis V. Structures of sequential open states in a symmetrical opening transition of the TolC exit duct. Proc Natl Acad Sci U S A 2011;108:2112-7.

23 Hinchliffe P, Symmons MF, Hughes C, Koronakis V. Structure and operation of bacterial tripartite pumps. Annu Rev Microbiol 2013;67:221-42.

24 Yamaguchi A, Nakashima R, Sakurai K. Structural basis of RND-type multidrug exporters. Front Microbiol 2015;6:327.

25 Müller RT, Pos KM. The assembly and disassembly of the AcrAB-TolC three-component multidrug efflux pump. Biol Chem 2015;396:1083-9.

26 Daury L, Orange F, Taveau JC, Verchère A, Monlezun L, Gounou C, Marreddy RK, Picard M, Broutin I, Pos KM, Lambert O. Tripartite assembly of RND multidrug efflux pumps. Nat Commun 2016;7:10731. 
27 Du D, Wang Z, James NR, Voss JE, Klimont E, Ohene-Agyei T, Venter H, Chiu W, Luisi BF. Structure of the AcrAB-TolC multidrug efflux pump. Nature 2014;509:512-15.

2728 Cohen SP, Hooper DC, Wolfson JS, Souza KS, McMurry LM, Levy SB. Endogenous active efflux of norfloxacin in susceptible Escherichia coli. Antimicrob Agents Chemother 1988;32:1187-91.

2829 Cohen SP, McMurry LM, Hooper DC, Wolfson JS, Levy SB. Crossresistance to fluoroquinolones in multiple-antibiotic-resistant (Mar) Escherichia coli selected by tetracycline or chloramphenicol: decreased drug accumulation associated with membrane changes in addition to OmpF reduction. Antimicrob Agents Chemother 1989;33:1318-25.

2930 Li XZ, Livermore DM, Nikaido H. Role of efflux pump(s) in intrinsic resistance of Pseudomonas aeruginosa: resistance to tetracycline, chloramphenicol, and norfloxacin Antimicrob Agents Chemother 1994;38:1732-41.

3031 Ocaktan A, Yoneyama H, Nakae T. Use of fluorescence probes to monitor function of the subunit proteins of the MexA-MexB-OprM drug extrusion machinery in Pseudomonas aeruginosa. J Biol Chem 1997;272:21964-9.

3132 Germ M, Yoshihara E, Yoneyama H, Nakae T. Interplay between the efflux pump and the outer membrane permeability barrier in fluorescent dye accumulation in Pseudomonas aeruginosa. Biochem Biophys Res Commun 1999;261:452-5.

3233 Martins M, Santos B, Martins A, Viveiros M, Couto I, Cruz A, et al. Management Committee Members; of Cost B16; European Commission/European Science Foundation. An instrument-free method for 
the demonstration of efflux pump activity of bacteria. In Vivo 2006;20:65764.

3334 Martins A, Spengler G, Martins M, Rodrigues L, Viveiros M, Davin-Regli A, et al. Physiological characterisation of the efflux pump system of antibioticsusceptible and multidrug-resistant Enterobacter aerogenes. Int $\mathrm{J}$ Antimicrob Agents 2010;36:313-8.

3435 Martins M, Viveiros M, Couto I, Costa SS, Pacheco T, Fanning S, et al. Identification of efflux pump-mediated multidrug-resistant bacteria by the ethidium bromide-agar cartwheel method. In Vivo 2011;25:171-8.

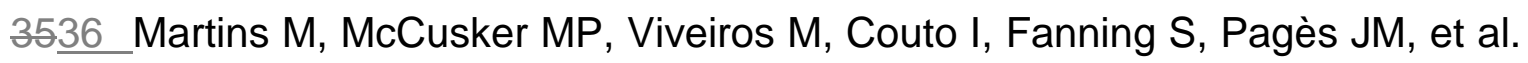
A simple method for assessment of MDR bacteria for over-expressed efflux pumps. Open Microbiol J 2013;7:72-82.

3637 Viveiros M, Martins A, Paixão L, Rodrigues L, Martins M, Couto I, Fähnrich E, Kern WV, Amaral L. Demonstration of intrinsic efflux activity of Escherichia coli K-12 AG100 by an automated ethidium bromide method. Int J Antimicrob Agents 2008;31:458-62.

$37 \underline{38}$ Bohnert JA, Karamian B, Nikaido H. Optimized Nile Red efflux assay of AcrAB-TolC multidrug efflux system shows competition between substrates. Antimicrob Agents Chemother 2010;54:3770-5.

3839 Bohnert JA, Schuster S, Szymaniak-Vits M, Kern WV. Determination of real-time efflux phenotypes in Escherichia coli AcrB binding pocket phenylalanine mutants using a 1,2'-dinaphthylamine efflux assay. PLoS ONE 2011;6:e21196.

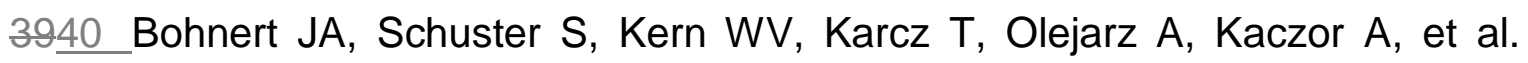
Novel piperazine arylideneimidazolones inhibit the AcrAB-TolC pump in 
Escherichia coli and simultaneously act as fluorescent membrane probes in a combined real-time influx and efflux assay. Antimicrob Agents Chemother 2016;60:1974-83.

4041 Husain F, Nikaido H. Substrate path in the AcrB multidrug efflux pump of Escherichia coli. Mol Microbiol 2010;78:320-30.

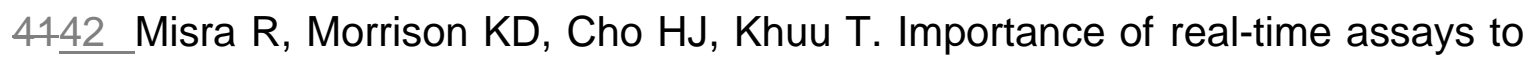
distinguish multidrug efflux pump inhibiting and outer membrane destabilizing activities in Escherichia coli. J Bacteriol 2015;197:2479-88.

4243 Nagano K, Nikaido H. Kinetic behavior of the major multidrug efflux pump AcrB of Escherichia coli. Proc Natl Acad Sci U S A. 2009; 106:5854-5858.

4344 Lim SP, Nikaido H. Kinetic parameters of efflux of penicillins by the multidrug efflux transporter AcrAB-TolC of Escherichia coli. Antimicrob Agents Chemother. 2010; 54:1800-1806.

$44 \underline{45}$ Kinana AD, Vargiu AV, May T, Nikaido H. Aminoacyl $\beta$-naphthylamides as substrates and modulators of AcrB multidrug efflux pump. Proc Natl Acad Sci U S A. 2016;113:1405-1410.

4546 Hirai K, Aoyama H, Irikura T, lyobe S, Mitsuhashi S. Differences in susceptibility to quinolones of outer membrane mutants of Salmonella typhimurium and Escherichia coli. Antimicrob Agents Chemother 1986;29:535-8.

4647 Hirai K, Suzue S, Irikura T, lyobe S, Mitsuhashi S. Mutations producing resistance to norfloxacin in Pseudomonas aeruginosa. Antimicrob Agents Chemother 1987;31:582-6.

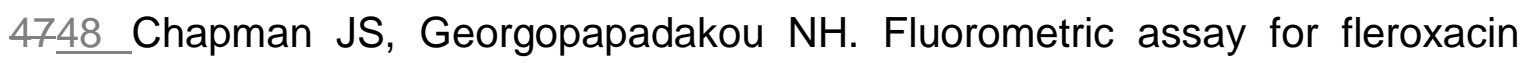
uptake by bacterial cells. Antimicrob Agents Chemother 1989;33:27-9. 
4849 De Zeeuw JR. Accumulation of tetracyclines by Escherichia coli. J Bacteriol 1968;95:498-506.

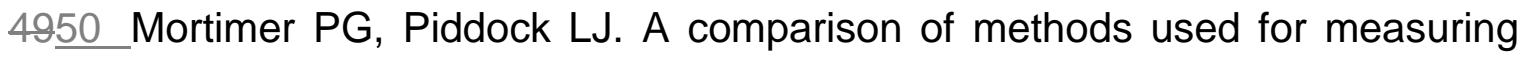
the accumulation of quinolones by Enterobacteriaceae, Pseudomonas aeruginosa and Staphylococcus aureus. J Antimicrob Chemother $1991 ; 28: 639-53$.

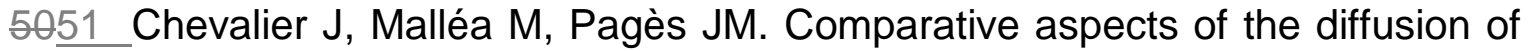
norfloxacin, cefepime and spermine through the $F$ porin channel of Enterobacter cloacae. Biochem J 2000;348:223-7.

$51 \underline{52}$ Baucheron S, Imberechts H, Chaslus-Dancla E, Cloeckaert A. The AcrB multidrug transporter plays a major role in high-level fluoroquinolone resistance in Salmonella enterica serovar typhimurium phage type DT204. Microb Drug Resist 2002; 8:281-9.

5253 Yu EW, Aires JR, McDermott G, Nikaido H. A periplasmic drug-binding site of the AcrB multidrug efflux pump: a crystallographic and site-directed mutagenesis study. J Bacteriol 2005;187:6804-15.

5354 Cinquin B, Maigre L, Pinet E, Chevalier J, Stavenger RA, Mills S, et al. Microspectrometric insights on the uptake of antibiotics at the single bacterial cell level. Sci Rep $2015 ; 5: 17968$.

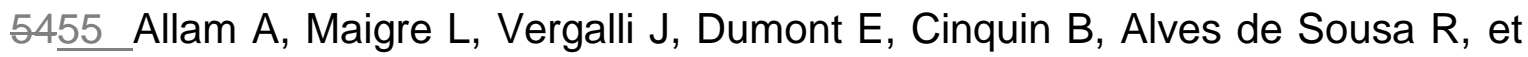
al. Microspectrofluorimetry to dissect the permeation of ceftazidime in Gram-negative bacteria. Sci Rep 2017;7:986.

5556 Zhao G, Meier TI, Kahl SD, Gee KR, Blaszczak LC. Bocillin FL, a sensitive and commercially available reagent for detection of penicillin-binding proteins. Antimicrob Agents Chemother 1999;43:1124-8. 


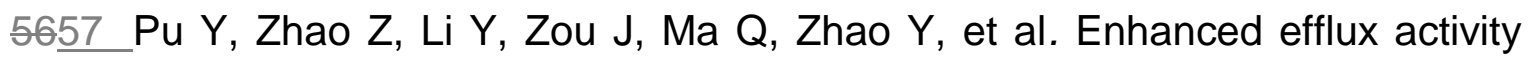
facilitates drug tolerance in dormant bacterial cells. Mol Cell 2016;62:28494.

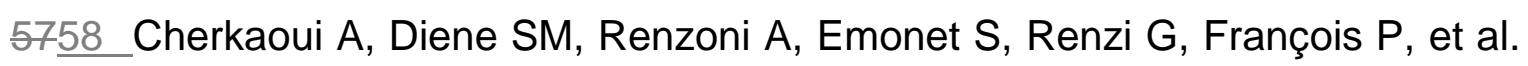
Imipenem heteroresistance in nontypeable Haemophilus influenzae is linked to a combination of altered PBP3, slow drug influx and direct efflux regulation. Clin Microbiol Infect 2017;23:118.e9-118.e19.

$58 \underline{59}$ Vergalli J, Dumont E, Cinquin B, Maigre L, Pajovic J, Bacqué E, Mourez M, Réfrégiers M, Pagès JM. Fluoroquinolone structure and translocation flux across bacterial membrane. Sci Rep 2017;7:9821.

$59 \underline{60}$ Pagès JM, Peslier S, Keating TA, Lavigne JP, Nichols WW. Role of the outer membrane and porins in susceptibility of $\beta$-lactamase-producing Enterobacteriaceae to ceftazidime-avibactam. Antimicrob Agents Chemother 2015;60:1349-59.

6061 Nikaido $H$. Role of permeability barriers in resistance to B-lactams antibiotics. Pharmac Ther 1985;27:197-231.

$61 \underline{62}$ Nikaido H. Outer membrane barrier as a mechanism of antimicrobial resistance. Antimicrob Agents Chemother 1989;33:1831-6.

6263 Zgurskaya HI, Nikaido H. Bypassing the periplasm: reconstitution of the AcrAB multidrug efflux pump of Escherichia coli. Proc Natl Acad Sci U S A. 1999;96:7190-5.

$63 \underline{64}$ Picard M, Verchère A, Broutin I. Monitoring the active transport of efflux pumps after their reconstitution into proteoliposomes: caveats and keys. Anal Biochem 2012;420:194-6. 
$64 \underline{65}$ Verchère A, Broutin I, Picard M. Photo-induced proton gradients for the in vitro investigation of bacterial efflux pumps. Sci Rep 2012;2:306.

$65 \underline{66}$ Verchère A, Dezi M, Adrien V, Broutin I, Picard M. In vitro transport activity of the fully assembled MexAB-OprM efflux pump from Pseudomonas aeruginosa. Nat Commun 2015;6:6890.

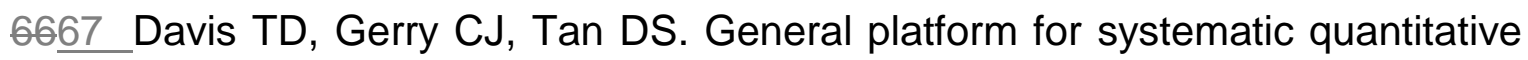
evaluation of small-molecule permeability in bacteria. ACS Chem Biol 2014;9:2535-44.

$67 \underline{68}$ Brown AR, Ettefagh KA, Todd D, Cole PS, Egan JM, Foil DH, et al. A mass spectrometry-based assay for improved quantitative measurements of efflux pump inhibition. PLoS ONE 2015;10:e0124814.

$68 \underline{69}$ Richter MF, Drown BS, Riley AP, Garcia A, Shirai T, Svec RL, et al. Predictive compound accumulation rules yield a broad-spectrum antibiotic. Nature 2017;545:299-304. 


\section{Legends for Figures}

Figure 1: Identification of efflux pump-mediated multidrug-resistant bacteria by the ethidium bromide-agar cartwheel method.

Left: Cartwheel pattern for the swabbing of the bacterial strains tested by the EtBragar cartwheel method. Controls and clinical isolates were swabbed on an EtBrcontaining agar plate, according to the diagram.

Right: Example of the EtBr-agar cartwheel method applied to Enterobacter aerogenes strains on agar plates containing $1.5 \mathrm{mg} / \mathrm{l}$ of $\mathrm{EtBr}$. Following overnight incubation at $37^{\circ} \mathrm{C}$ for 16 hours, fluorescence was detected under UV light. (from [34]).

Figure 2: Real-time efflux assay using fluorescent probes.

(A) Protocol of the real-time efflux method. The cells are preloaded with a dye which is fluorescent in nonpolar environments such as bacterial membranes. Addition of glucose energizes the efflux pump and triggers the dye efflux across the envelope, leading to the decrease of fluorescence.

(B) Representative 1,2'-DNA efflux curves of $E$. aerogenes EA289, a clinical isolate overexpressing AcrAB efflux pumps, and EA298 its tolC- derivative. Fluorescence of the $A c r A B$ overexpressing strain is decreasing while the fluorescence of the strain devoid of TolC is stable.

Figure 3: Determination of antibiotic concentration in bacteria using spectrofluorimetry. 
(A) Protocol of the spectrofluorimetry method: After incubation of bacteria with the antibiotic, bacteria cells are washed onto a sucrose cushion in order to avoid nonspecific adsorption on the cell surface. The cells are then lysed overnight and the fluorescence intensity of the intracellular content is measured.

(B) Representative fluorescence curves corresponding to the lysates of the overexpressing AcrAB efflux pump strain E. aerogenes EA289 and its tolC- derivative strain EA298, incubated with fleroxacin with or without CCCP.

Upper panel: kinetic of fleroxacin accumulation in the cells during $1 \mathrm{~h}$ of incubation.

Lower panel: Peaks of fluorescence (corresponding to the fleroxacin emission wavelength) of the lysates sampled at 15 minutes of incubation.

Figure 4: Fluoroquinolone time-course accumulation in individual bacterial cells using DUV microspectrofluorimetry.

(A) Average fluorescence intensity time course of 100 individual cells of the overexpressing AcrAB efflux pump strain E. aerogenes EA289 (solid line) and its tolC- derivative strain EA298 (dashed line) incubated with fleroxacin. (from [53]).

(B) Images taken by microscopy of isolated bacterium accumulating fleroxacin. (C) Antibacterial activities and spectral properties of fleroxacin. MIC (Minimal inhibitory concentration) are indicated in mg/L; PMBN (Polymyxin B nonapeptide) was used at $51.2 \mathrm{mg} / \mathrm{L}, \mathrm{PABN}$ (Phenylalanine-arginine-ß-naphthylamide) at $20 \mathrm{mg} / \mathrm{L}$ and CCCP (carbonyl cyanide m-chlorophenylhydrazone) at $10 \mu \mathrm{M}$. (D) Scheme of the translocation of fleroxacin (FLX) in a gram-negative bacterial cell. $[F L X]_{\text {ext: }}$ : Concentration of fleroxacin in the external environment, $[F L X]_{p p}$ in the periplasmic space, $[F L X]_{c y t}$ in cytoplasm. (E) Microspectrofluorimetry on bacterial cells incubated with fleroxacin (Fle) for $10 \mathrm{~min}$. In the parental strain, AG100, the fluorescence was 
less intense that the ones obtained in AG100A, the AcrAB deleted strain. When the incubation of the efflux overproducer strain (AG102) was performed in the presence of CCCP that collapse the energy driving force of efflux pump, a signal similar to those in AG100A was obtained.

Figure 5: Reconstitution of efflux pumps in proteoliposomes.

(A) Schematic representation of the MexA-MexB-OprM pump from Pseudomonas aeruginosa (Adapted from [64]).

(B) Cartoon representation of liposomes reconstituted with bacteriorhodopsin (BR) from Halobacter halobium (upper scheme) or with both $\mathrm{BR}$ and MexB were reconstituted in liposomes containing pyranine (lower scheme). BR is used to generate a photo-induced proton gradient to activate the MexB efflux pump. After illumination of the proteoliposomes, BR generates a transmembrane proton gradient, which is then used by MexB to transport a fluorescent dye. (C) Monitoring of the liposomal acidification upon illumination. Pyranine fluorescence variations, as a result of MexB efflux activity, were normalized to the corresponding $\mathrm{pH}$ variations based on titration of the fluorescence variation as a function of $\mathrm{pH}$. MexB is active only in the presence of the periplasmic adaptor MexA. 